Provided for non-commercial research and education use. Not for reproduction, distribution or commercial use.

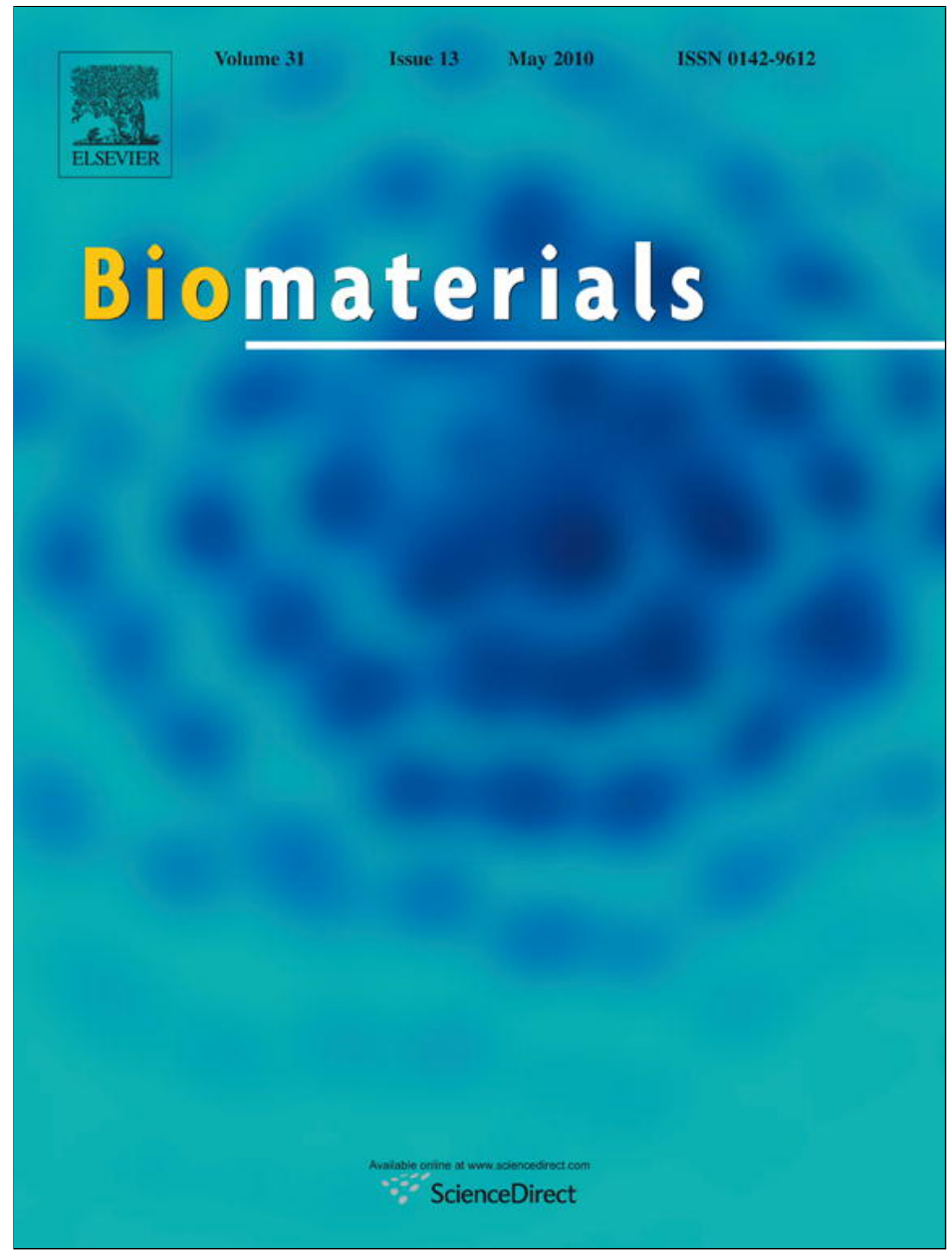

This article appeared in a journal published by Elsevier. The attached copy is furnished to the author for internal non-commercial research and education use, including for instruction at the authors institution and sharing with colleagues.

Other uses, including reproduction and distribution, or selling or licensing copies, or posting to personal, institutional or third party websites are prohibited.

In most cases authors are permitted to post their version of the article (e.g. in Word or Tex form) to their personal website or institutional repository. Authors requiring further information regarding Elsevier's archiving and manuscript policies are encouraged to visit:

http://www.elsevier.com/copyright 


\title{
Characterization of topographical effects on macrophage behavior in a foreign body response model
}

\author{
Sulin Chen ${ }^{\mathrm{a}, \mathrm{b}}$, Jacqueline A. Jones ${ }^{\mathrm{c}}$, Yongan $\mathrm{Xu}^{\mathrm{d}}$, Hong-Yee Low ${ }^{\mathrm{d}}$, James M. Anderson ${ }^{\mathrm{c}}$, Kam W. Leong ${ }^{\mathrm{a}, *}$ \\ a Department of Biomedical Engineering, Duke University, Durham, NC 27708, USA \\ ${ }^{\mathrm{b}}$ Department of Biomedical Engineering, Johns Hopkins University, Baltimore, MD 21218, USA \\ ${ }^{\mathrm{c}}$ Department of Biomedical Engineering, Case Western University, Cleveland, $\mathrm{OH} 44106$, USA \\ ${ }^{\mathrm{d}}$ Institute of Materials Research and Engineering, 3 Research Link, Singapore 117602, Singapore
}

\section{A R T I C L E I N F O}

\section{Article history:}

Received 22 December 2009

Accepted 13 January 2010

Available online 6 February 2010

\section{Keywords:}

Microtopography

Nanotopography

Foreign body response

Nanostructured biomaterials

Inflammation and wound healing

Cytokines

\begin{abstract}
A B S T R A C T
Current strategies to limit macrophage adhesion, fusion and fibrous capsule formation in the foreign body response have focused on modulating material surface properties. We hypothesize that topography close to biological scale, in the micron and nanometric range, provides a passive approach without bioactive agents to modulate macrophage behavior. In our study, topography-induced changes in macrophage behavior was examined using parallel gratings ( $250 \mathrm{~nm}-2 \mu \mathrm{m}$ line width) imprinted on poly ( $\epsilon$-caprolactone) (PCL), poly(lactic acid) (PLA) and poly(dimethyl siloxane) (PDMS). RAW 264.7 cell adhesion and elongation occurred maximally on $500 \mathrm{~nm}$ gratings compared to planar controls over $48 \mathrm{~h}$. TNF- $\alpha$ and VEGF secretion levels by RAW 264.7 cells showed greatest sensitivity to topographical effects, with reduced levels observed on larger grating sizes at $48 \mathrm{~h}$. In vivo studies at 21 days showed reduced macrophage adhesion density and degree of high cell fusion on $2 \mu \mathrm{m}$ gratings compared to planar controls. It was concluded that topography affects macrophage behavior in the foreign body response on all polymer surfaces examined. Topography-induced changes, independent of surface chemistry, did not reveal distinctive patterns but do affect cell morphology and cytokine secretion in vitro, and cell adhesion in vivo particularly on larger size topography compared to planar controls.
\end{abstract}

(c) 2010 Elsevier Ltd. All rights reserved.

\section{Introduction}

Monocyte and macrophage cells play a key role in mediating host tissue response to implants in the foreign body reaction [1-3]. This response is characterized by non-specific protein adsorption onto the implant surface, followed by monocyte attachment and differentiation into adherent macrophage cells on the surface. The activated macrophages secrete cytokines to recruit leukocytes and other cell types involved in the foreign body reaction, and further mediate inflammation and wound healing/remodeling around the site of implant. Within 2-4 weeks, unresolved inflammation, marked by macrophage fusion into large multi-nucleated foreign body giant cells (FBGCs) surround the implant in a fibrotic scar tissue. The FBGCs may release oxygen radicals, degradative enzymes and acid that contribute to implant degradation and eventual failure.

Current strategies to mediate the foreign body reaction focus on reducing protein adsorption, initial cell adhesion, inflammatory

\footnotetext{
* Corresponding author at: Department of Biomedical Engineering, Duke University, Box 90281, Durham, NC 27708, USA. Tel.: +19196608421.

E-mail address: kam.leong@duke.edu (K.W. Leong).
}

cytokine secretion and FBGC fusion. They assume two general approaches: (1) modulation of chemical and physical properties of the implant surface, and (2) incorporation of bioactive cues onto the material to mediate material-host tissue interaction. In the first approach, materials engineering designs include improving wearresistant property of polymeric and metallic implants [4] and modifying surface wettability, charge and crystallinity [5-7]. Surface chemistry [8-11], roughness [12,13], substrate stiffness [14,15], and geometry [16] have also been altered to study their effects on cell adhesion and responses associated with foreign body reaction. In the second approach, biomimetic "smart" materials with functional activity in the form of surface functionalization or polymer coatings that release or generate soluble small molecules have been used to mediate implant-host tissue response. For example, coatings that release or generate nitric oxide (NO) reduce thrombogenesis and inflammation [17-19] and hydroxyapatite coatings on titanium alloys improve osteointegration in orthopedic implants [20]. Chemokines, cytokines and soluble molecules such as IL-4, IL-13 and $\alpha$-tocopherol can mediate FBGC formation in vitro [21-23], including the expression of different $\beta$-integrin subunits temporally [24], while surface-tethered or adsorbed vitronectin has 
been shown to be a key component in macrophage activation and FBGC formation [25].

For simplicity and regulatory considerations, a passive approach of modifying the physicochemical properties without resorting to addition of bioactive agents would be preferred in an implant design. In addition to the physicochemical factors discussed above, topography is increasingly recognized as an important cue that influences cellular response [26-29]. In vivo extracellular matrix (ECM) architecture shown in scanning electron micrographs of basement membranes and collagen fibers often reveal a topography of pores, ridges and fibrillar structures at the micron and nanometer scales $[30,31]$. Recent studies show that macrophage activation and FBGC formation respond to differing polymer fiber diameter [32,33], surface roughness [34,35] and geometry [36]. These findings highlight the possibility of using topography to mediate implant-tissue reaction, and stimulate the current study to systematically investigate the effects of topographical features on macrophage culture.

In this study, we examine the response of macrophage cells to nano- and microgratings composed of commonly used biomedical polymers in this study. Poly( $\epsilon$-caprolactone) (PCL), poly(lactic acid) (PLA) and poly(dimethyl siloxane) (PDMS) gratings with line width ranging from $250 \mathrm{~nm}$ to $2 \mu \mathrm{m}$ were fabricated by reversal nanoimprint lithography and embossing technique. The in vitro early response of RAW 264.7 cells to these synthetic topographies with respect to adhesion, morphology and cytokine secretion was characterized. Samples of PCL gratings nanoimprinted on Mylar were evaluated in rats using the cage implant model to determine the effect of topography on foreign body reaction.

\section{Materials and methods}

All chemicals and polymers were purchased from Sigma-Aldrich (St. Louis, MO) and cell culture reagents were purchased from GibcoBRL (Grand Island, NY), unless otherwise specified.

\subsection{Substrate fabrication and characterization}

Reversal nanoimprint lithography (NIL) techniques previously developed $[37,38]$ were used to fabricate gratings of poly(lactic acid) (PLA, Mw 60,000) and poly( $\epsilon$-caprolactone) (PCL, Mw 65,000) with a line width ranging from $250 \mathrm{~nm}$ to 2 $\mu \mathrm{m}$ approximating the length scales of fibrillar structures observed in native ECM but with precisely defined anisotropic topographical cues (Fig. 1A). Briefly, PCL and PLA polymer films are coated onto silicon molds and heated above the glass transition temperatures $\left(T_{\mathrm{g}}\right)$ to "flow" and acquire the topography of the molds. Then, plasma-treated glass and Mylar substrates are pressed against the polymer coated molds. The sandwich structures are then placed inside a NIL-4" imprinter (Obducat, Sweden), and imprinting completed at $150{ }^{\circ} \mathrm{C}$ and $4 \mathrm{MPa}$. The polymer films are allowed to cool below its $T_{\mathrm{g}}$ before de-molding, with the desired topography transferred from the molds to the plasma-treated substrates with higher surface energy. Glass and Mylar substrates were selected for its optical properties in fluorescence imaging and as a model polymer used in implants, respectively. The gratings consist of constant spacing of $250 \mathrm{~nm}, 500 \mathrm{~nm}$, and $2 \mu \mathrm{m}$ apart (width: height:period $=1: 1: 2$ ). NIL manipulates the $T_{\mathrm{g}}$ and thermo-viscosity of polymers to transfer topographical relief from a rigid mold onto the polymer. It provides a great degree of flexibility in choice of polymeric materials, patterns and imprinting process parameters to obtain topographical patterns of great fidelity ranging from the micron to nanometric scale $[39,40]$. Controls were fabricated by embossing PCL (heated to $62{ }^{\circ} \mathrm{C}$ ) on silicon wafers and allowed to cool to room temperature, resulting in planar PCL controls with surface roughness of less than $4 \AA$.

To isolate 3-dimensional effects of topographical depth (compared to NIL substrates with a range of $250 \mathrm{~nm}-2 \mu \mathrm{m}$ depth), we adapted a hybrid technique of soft lithography, stitching and embossing to imprint parallel lines onto poly(dimethyl siloxane) (PDMS) (Sylgard ${ }^{\circledR} 184$, Dow Corning, 10:1 pre-polymer:curing agent) (Fig. 1B). Briefly, the hybrid technique serially transferred patterns from a primary silicon mold $\left(5 \times 5 \mathrm{~mm}^{2}\right)$ to secondary PDMS replicas using traditional soft lithography. The secondary PDMS replicas were stitched into a larger secondary mold, and embossed onto a tertiary polystyrene-coated silicon wafer (at least $35 \times 35 \mathrm{~mm}^{2}$ ). The tertiary mold was used to fabricate PDMS replicas of grating widths $300 \mathrm{~nm}, 500 \mathrm{~nm}$ and $1 \mu \mathrm{m}$ spaced equally apart (width:period =1:2) and constant height $(350 \mathrm{~nm})$. Planar PDMS controls were fabricated by heat curing on planar silicon wafers for a smooth surface (width $=0 \mathrm{~nm}$ ).

The pattern transfer fidelity from mold to replica was examined using scanning electron microscopy (SEM) (FEI XL30 SEM-FEG) and atomic force microscopy (AFM) (Veeco Dimension 3100). Samples were coated with a $10 \mathrm{~nm}$ layer of gold film (Denton Desk IV vacuum sputter coater) to improve sample conductivity for SEM imaging. Topography dimensions were measured using AFM tapping mode $(20 \times 20$ $\mu \mathrm{m}^{2}$ scan areas) with silicon TESP probes. The $O / E$ value, a ratio of the observed value
A

Nano-Imprinting Lithography

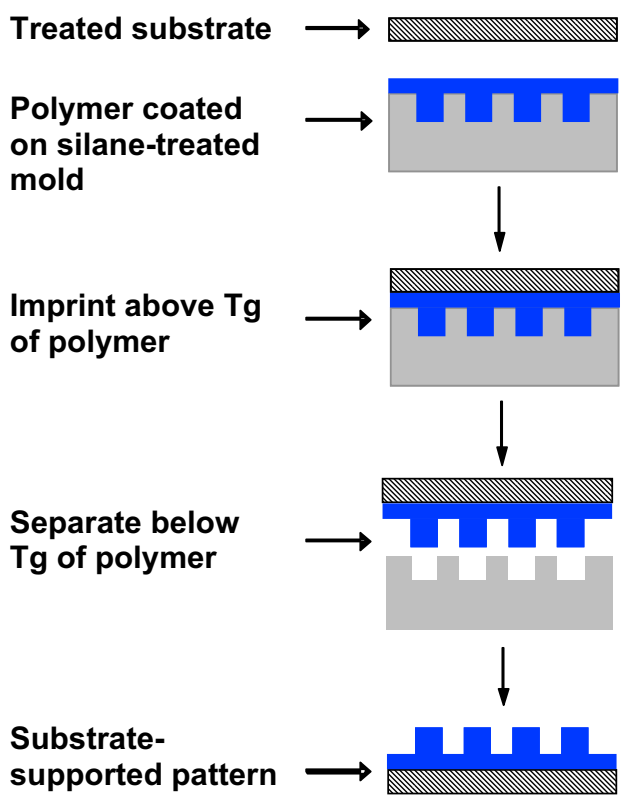

B

Hybrid Technique: Soft Lithography, Stitching \& Embossing

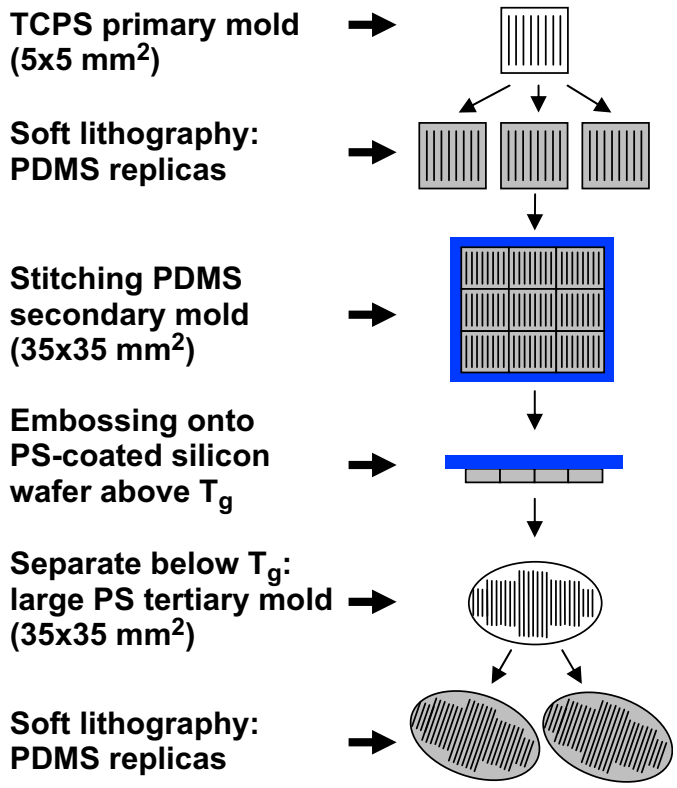

Fig. 1. Topographical substrate fabrication process. Schematics of (A) the nanoimprint lithography fabrication process, and (B) the hybrid fabrication technique combining soft lithography, stitching and embossing. PCL and PLA gratings were fabricated using the NIL technique, and PDMS gratings were fabricated using the hybrid technique. 

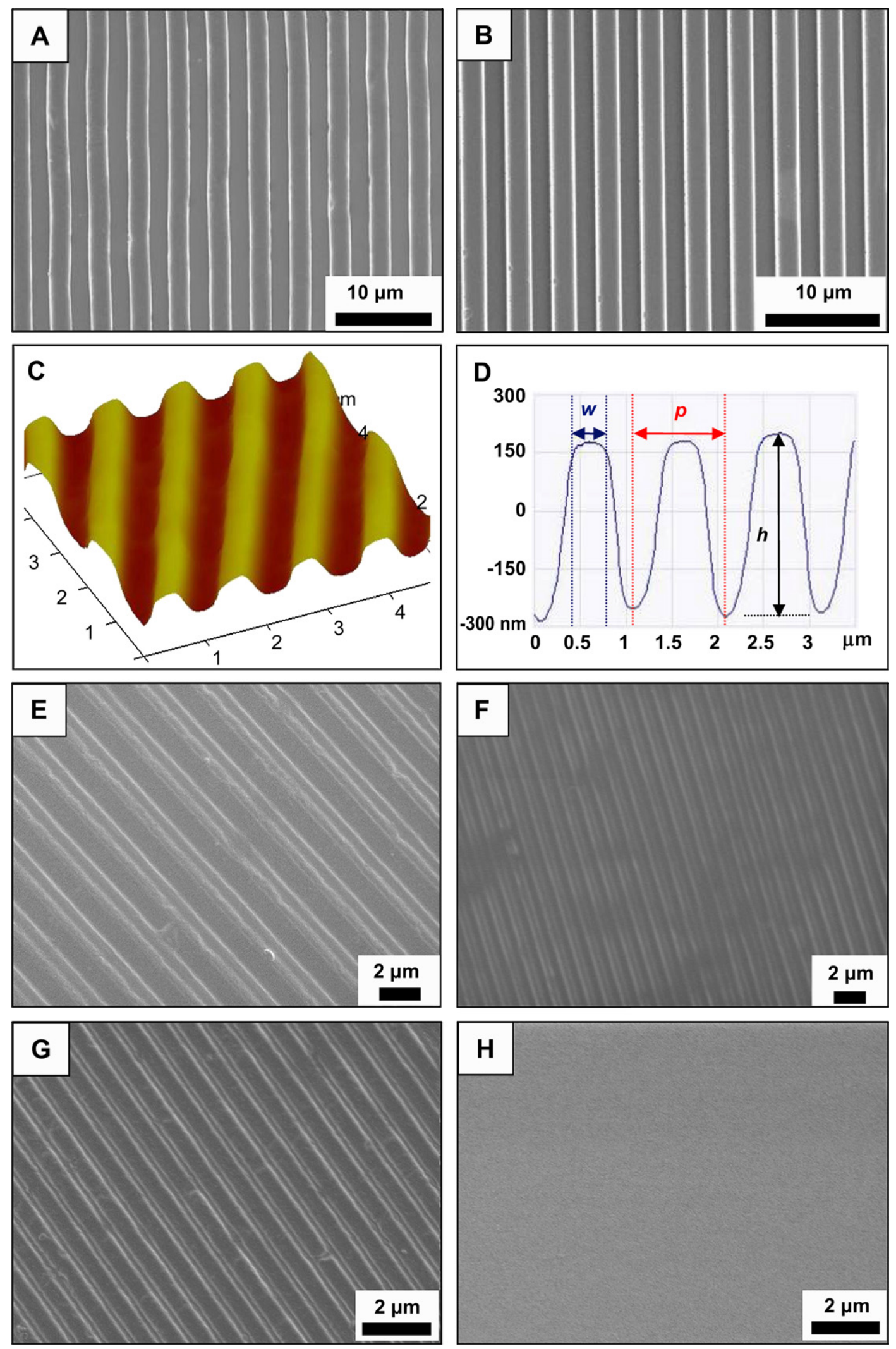

Fig. 2. Substrate characterization. SEM micrographs of substrates fabricated using NIL technique: (A) $2 \mu \mathrm{m}$ PCL gratings, and (B) $2 \mu \mathrm{m}$ PLA gratings on treated glass. AFM characterization of (C) a $5 \times 5 \mu^{2}$ scan area on a $500 \mathrm{~nm}$ PCL sample imprinted on Mylar showed (D) dimensions of $500 \mathrm{~nm}$ width $(w) 500 \mathrm{~nm}$ height $(h)$ and $1 \mu \mathrm{m}$ period $(p)$. SEM micrographs of constant height PDMS gratings showed that the hybrid technique was successful in transferring patterns from rigid mold to PDMS replicas with high fidelity: (E) $1 \mu \mathrm{m}$ grating width, (F) $500 \mathrm{~nm}$ gratings width, (G) $300 \mathrm{~nm}$ gratings width, and (H) planar controls. Scale bar = $10 \mu \mathrm{m}(\mathrm{A}-\mathrm{B})$, and $2 \mu \mathrm{m}(\mathrm{E}-\mathrm{H})$. 
$(O)$ of the width, period or height to the expected value $(E)$, provides a measurement of the deviation of fabricated topography from the ideal (i.e. ideal $O / E=1.00$ ).

\subsection{Cell culture and immunohistochemistry staining}

Adherent murine macrophage cell line, RAW 264.7 (ATCC, Manassas, VA), was grown in Dulbecco's Modified Eagle's Medium (DMEM) cell culture media supplemented with $10 \%$ fetal bovine serum, penicillin $(100 \mu \mathrm{g} / \mathrm{mL})$ and streptomycin $(100$ $\mu \mathrm{g} / \mathrm{mL}$ ). Immediately prior to use, PCL and PLA grating samples $\left(5 \times 5 \mathrm{~mm}^{2}\right)$ were sterilized in $10 \%$ penicillin-streptomycin (diluted in phosphate buffer saline, $\mathrm{PBS}, \mathrm{pH}$ 7.4) for $1 \mathrm{~h}$, and rinsed twice in PBS before cell seeding. PDMS grating samples were cut into $21 \mathrm{~mm}$ diameter discs and sterilized with $70 \%$ ethanol in place of $10 \%$ penicillin-streptomycin. Cells were seeded onto sterile samples at $2 \times 10^{4} \mathrm{cells} / \mathrm{cm}^{2}$ in $2 \mathrm{~mL}$ fresh culture media in 12 -well TCPS plates. Triplicates $(n=3)$ of each grating size were used for each time point. The plates were maintained in an incubator at 37 ${ }^{\circ} \mathrm{C}$ temperature, $5 \% \mathrm{CO}_{2}$ : 95\% humidified air for $6 \mathrm{~h}, 24 \mathrm{~h}$ and $48 \mathrm{~h}$ to study cell adhesion, morphology changes and cytokine secretion in response to topographical cues. Supernatant collected was centrifuged to remove cell debris and stored at -80 ${ }^{\circ} \mathrm{C}$ until assayed for cytokine concentration.

At each time point, adherent cells on the gratings were fixed in $4 \%$ paraformaldehyde for $10 \mathrm{~min}$ in preparation for fluorescence microscopy imaging. Cells were permeabilized in $0.02 \%$ Triton $-x$ for $20 \mathrm{~min}$, followed by staining with Phalloidin Oregon-Green 488 and DAPI (Molecular Probes) for F-actin and cell nuclei, respectively, for $30 \mathrm{~min}$. Each step was preceded and followed by a brief PBS rinse. Samples were mounted onto glass cover slips with Gel/Mount (Biomeda) before imaging. Similarly, samples were prepared for optical microscopy imaging by ice-cold methanol fixation for $5 \mathrm{~min}$, then allowed to air dry, followed by MayGrünwald Giemsa staining. Stained samples were allowed to further air-dry before digital imaging (ImagePro, Media Cybernetics) with a fluorescence and light microscope (Nikon TE2000U). 8-10 images of separate random regions $(20 \times$ and $40 \times$ magnification) were taken per sample. Morphology measurements were made from at least 150 cells in each triplicate sample $(n=3)$ per grating size. The $R$-ratio, a measure of elongation morphology change, was determined as the ratio of length of major axis:length of minor axis of a cell. A perfectly round cell has an elongation factor of $R=1$. Elongated cells were defined as having $R \geq 2.5$ and angled within $30^{\circ}$ of the gratings. Image analysis was performed using Image (NIH, Bethesda, MD) and ImagePro (Media Cybernetics).

SEM was used to examine cell interaction with its underlying topography. Adherent cells on gratings were prepared for SEM imaging using standard protoco of fixation and serial dehydration in ethanol and hexamethyldisilazane (HMDS). All samples were allowed to vacuum-dry overnight before sputter coating (Denton Desk IV) of a $10 \mathrm{~nm}$ gold layer.

\subsection{Cytokine secretion profile immunoassays}

The cytokine secretion profile of RAW 264.7 in response to topography was examined on a Bio-Plex array system reader (Bio-Rad) using a multiplex suspension bead immunoassay kit (Millipore) for 8 cytokines: TNF- $\alpha$, IL-1 $\beta$, MIP-1 $\alpha$, MCP-1, VEGF, IL-6, IL-10 and IL-12. Briefly, supernatant was incubated with antibodycoupled beads overnight at $4{ }^{\circ} \mathrm{C}$, followed by incubation of cytokine-bound beads with secondary antibody for $1 \mathrm{~h}$. Phycoerythrin dye was bound to the beads via biotin-streptavidin binding for $30 \mathrm{~min}$. All incubation steps were performed on a plate shaker at room temperature unless specified otherwise. Cytokine concentrations $(\mathrm{pg} / \mathrm{mL})$ in triplicates were measured from the mean fluorescence intensity readings and compared against 4- and 5-parameter logistic (4PL and 5PL) standard curves generated from readings of known concentration of cytokine standards provided in the kit. The Bio-Plex reader was calibrated and validated prior to every reading, strictly following the manufacturer's instructions.

\subsection{In vivo cage implant system}

PCL gratings imprinted on Mylar with line widths $2 \mu \mathrm{m}$ and $500 \mathrm{~nm}$ were cut into $1.5 \mathrm{~cm} \times 0.8 \mathrm{~cm}$ rectangular samples and prepared for subcutaneous implantation in the back of 12-week-old female Sprague-Dawley rats (Charles River, MA) using protocols as previously described [41-43]. Briefly, the samples were sterilized in $70 \%$ ethanol and ethylene oxide, then placed inside cylindrical surgical-grade stainless steel wire mesh cages $(3.5 \mathrm{~cm}$ length $\times 1.0 \mathrm{~cm}$ diameter). Cages containing one of each PCL/Mylar gratings ( $2 \mu \mathrm{m}$ and $500 \mathrm{~nm}$ ) were implanted on the latera sides on the back of an animal, using 3-5 animals for each grating size per time point. All protocols were approved by the Institutional Animal Care and Use Committee of Case Western Reserve University.

On days 7 and 21 post-implantation, the cage implants were explanted using previously described protocol [43]. Retrieved implants were stained with MayGrünwald Giemsa to evaluate adherent cell density and cellular fusion. Cellular adhesion was determined by the total number of nuclei in adherent cells including those in uni- and multi-nucleated cells in 8-10 fields-of-view of separate random regions (20× and $40 \times$ magnification) per sample. Cellular fusion was categorically estimated as the percentage of fusion in each field at $0 \%,<10 \%, 25 \% .50 \%, 75 \%,>90 \%$ and $100 \%$. A total of 24-72 fields were examined on 3-5 samples, and cellular fusion was presented as the percent of fields with the corresponding categorical percent fusion values. Cellular orientation to grating direction was similarly analyzed via optical microscopy and SEM. To examine cell-gratings interaction, the samples previously stained with May-Grünwald Giemsa were gently washed with distilled water to remove residual salt crystals, allowed to air dry, then sputter-coated with a $10 \mathrm{~nm}$ gold layer (Denton Desk IV) in preparation for SEM imaging.

\subsection{Statistical analysis}

Results are presented as mean \pm standard error of the mean. Statistical analysis was performed using Student's $t$-test or ANOVA followed by Tukey's post-hoc test, as appropriate. A level of $p<0.05$ (two-tailed) was considered statistically significant

\section{Results}

\subsection{Substrate fabrication and characterization}

NIL was successfully applied to fabricate various patterns on glass and Mylar. Fig. 2A and B show respectively the characteristic SEM of $2 \mu \mathrm{m}$ PCL gratings and $2 \mu \mathrm{m}$ PLA gratings imprinted on treated glass with a residual layer. A sample with a residual layer has gratings with ridges and troughs of the same polymeric material. Conversely, a residual layer-free sample created with further etching, would have ridges made of polymeric materials (PCL or PLA) but troughs made of substrate materials (glass or Mylar).

AFM characterization of the substrates measured its topography, as shown in a representative 3-dimensional projection of a $5 \times 5$ $\mu \mathrm{m}^{2}$ AFM scan of a $500 \mathrm{~nm}$ PCL gratings imprinted on Mylar sample (Fig. 2C). A cross-section of the 3-dimensional projection shows the gratings topography in terms of width $(w)$, period $(p)$ and height $(h)$ (Fig. 2D). Table 1 summarizes topography dimensions measured from AFM scans. A comparison of the observed values $(O)$ to the expected value $(E)$ of the topographical gratings showed fidelity to be within $8 \%$ of expected feature size $(O / E$ value of 1.08$)$. The only discrepancy in pattern transfer fidelity occurred with respect to the height of $250 \mathrm{~nm}$ substrates, which has an $O / E$ value of 0.46 . This discrepancy was attributed to the sensitivity limit of the AFM readings because the AFM tip was larger than the spacing between the gratings (250 nm apart), and could not measure the actual trough of $250 \mathrm{~nm}$ samples, hence providing a lower height $(h)$ value.

Similarly, the hybrid technique was successful in fabricating PDMS replicas with gratings of varying widths $(1 \mu \mathrm{m}, 500 \mathrm{~nm}$ and $300 \mathrm{~nm})$ at constant height (350 nm) (Fig. 2E-H).

Table 1

AFM characterization of PCL/Mylar gratings.

\begin{tabular}{lllll}
\hline Topography $^{\mathrm{a}}$ & & & & \\
\hline Substrates & & $\begin{array}{l}\text { Width, } w \\
(\mathrm{~nm})\end{array}$ & $\begin{array}{l}\text { Period, } p \\
(\mathrm{~nm})\end{array}$ & $\begin{array}{l}\text { Height, } h \\
(\mathrm{~nm})\end{array}$ \\
\hline $250 \mathrm{~nm}$ & $O^{\mathrm{b}}$ & $270(11)$ & $534(12)$ & $114(12)$ \\
& $E^{\mathrm{c}}$ & 250 & 500 & 250 \\
& $O / E$ & 1.08 & 1.07 & 0.46 \\
& $n^{\mathrm{d}}$ & 6 & 6 & 6 \\
$500 \mathrm{~nm}$ & $O$ & $518(18)$ & $1056(19)$ & $486(20)$ \\
& $E$ & 500 & 1000 & 500 \\
& $O / E$ & 1.04 & 1.06 & 0.97 \\
& $n$ & 4 & 4 & 4 \\
& $O$ & $2,064(162)$ & $4,047(51)$ & $1,972(253)$ \\
& $O$ & 2000 & 4000 & 2000 \\
& $E$ & 1.03 & 1.01 & 0.99 \\
& $O / E$ & 10 & 8 & 15 \\
\hline
\end{tabular}

a Data presented as mean (standard deviation).

b $\mathrm{O}=$ Observed value from AFM scan.

${ }^{c} E=$ Expected value of topography measurements.

d $n=$ Number of measurements. 


\subsection{Cell adhesion and morphology changes on NIL gratings}

RAW 264.7 was cultured on 3 different types of polymers, PCL, PLA and PDMS gratings, to examine macrophage response to topography independent of surface chemistry. Cells elongated on the PDMS topographical gratings (Fig. $3 \mathrm{~A}$ ) compared to its native round shape on planar PDMS controls after 48 h culture (Fig. 3B). This phenomenon was distinctively observed at the border of imprinted surfaces and its planar underlying substrates (Fig. 3C). Only on the $2 \mu \mathrm{m}$ PLA gratings did the cells clearly elongate in the direction of gratings (left portion), as illustrated by the immunostained F-actin (green) and nuclei (blue) of the cells. In contrast, cells retained their native round morphology on the planar surface (right portion), separated by the distinct border (dotted white line). The underlying PLA topography and its border may be clearly seen in a phase contrast image of the $2 \mu \mathrm{m}$ PLA gratings imprinted on glass (Fig. 3 D), along with adherent RAW 264.7 cells. Similarly, macrophages elongated in the direction of gratings on three different widths of PCL gratings imprinted on glass: $2 \mu \mathrm{m}$ (Fig. 3E), $500 \mathrm{~nm}$ (Fig. 3F), and $250 \mathrm{~nm}$ (Fig. 3G). In contrast, cells retained their native round shape on planar controls of glass (Fig. $3 \mathrm{H}$ ), planar PCL film (Fig. 3I) and tissue culture polystyrene (TCPS, Fig. 3J).

Analyzing the morphological changes in RAW 264.7 due to topography in greater detail, the average elongation ratio,
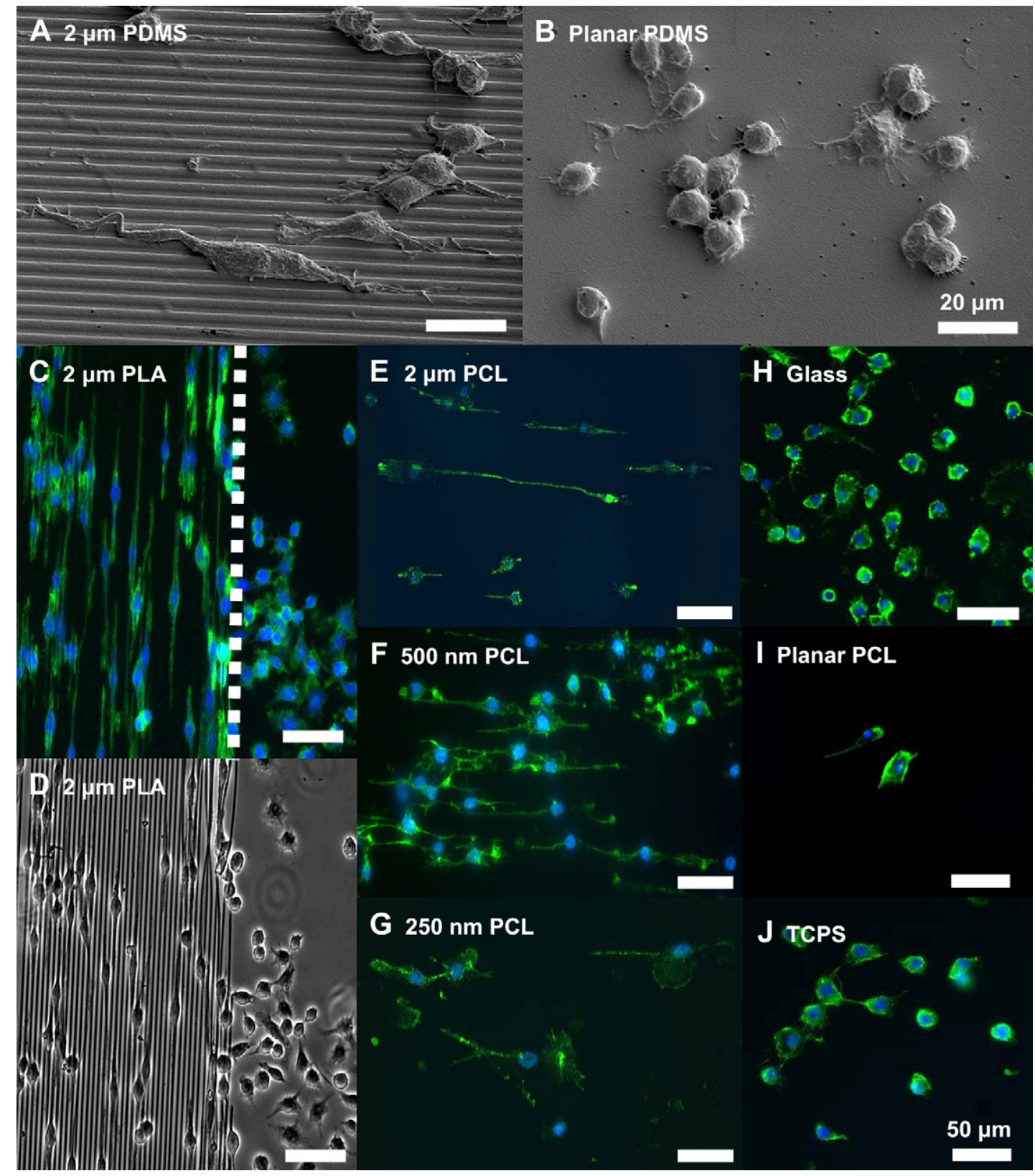

Fig. 3. Macrophage morphology changes on topographical gratings compared to planar controls. SEM micrographs of RAW 264.7 cultured on (A) $2 \mu \mathrm{m}$ PDMS gratings for $48 \mathrm{~h}$ showed that cells elongated in the direction of the gratings, but (B) maintained its native round morphology on the planar PDMS control. (C) Fluorescent staining of adherent RAW 264.7 cultured on $2 \mu \mathrm{m}$ PLA gratings imprinted on glass for $48 \mathrm{~h}$ showed distinct cell elongation in the direction of the gratings, in contrast to cells with round morphology on the planar border (dotted white line). (D) A phase contrast image of the sample clearly showed the border between the $2 \mu \mathrm{m}$ PLA gratings and its planar surface. Cell elongation was similarly observed on PCL gratings imprinted on glass at $48 \mathrm{~h}$ : (E) $2 \mu \mathrm{m}$ gratings width, (F) $500 \mathrm{~nm}$ gratings width, and (G) $250 \mathrm{~nm}$ gratings width. In contrast, cells retained its native round shape on planar controls such as (H) glass, (I) planar PCL film and (J) tissue culture polystyrene (TCPS). F-actin and cell nuclei immunostaining were performed by Phalloidin Oregon-Green488 (green) and DAPI (blue), respectively. Scale bar $=20 \mu \mathrm{m}(\mathrm{A}-\mathrm{B})$, and $50 \mu \mathrm{m}$ (C-J). 
$R$-ratio = length of major axis/length of minor axis, was measured for adherent cells on PCL gratings imprinted on Mylar (Fig. 4 A). Micro- and nanotopography significantly increased the average $R$-ratio of adherent macrophage on all surfaces compared to planar controls $\left({ }^{*} p<0.05\right)$, particularly on $500 \mathrm{~nm}$ gratings $\left({ }^{* *} p<0.01\right)$. The average $R$-ratio of macrophages on planar control was 1.78 , but increased to 2.18 on $250 \mathrm{~nm}$ gratings and 2.53 on $500 \mathrm{~nm}$ gratings, and then decreased slightly to 2.24 on $2 \mu \mathrm{m}$ gratings. The observed increase in $R$-ratio correlated with an increase in sub-population of cells attaining the elongated morphology, defined as having $R \geq 2.5$ and aligned within $30^{\circ}$ of the parallel gratings (Fig. 4B). The fraction of elongated cells increased from 0.10 on planar controls to 0.17 (66\% increase), 0.23 ( $123 \%$ increase) and 0.20 ( $85 \%$ increase) on 250 $\mathrm{nm}, 500 \mathrm{~nm}$ and $2 \mu \mathrm{m}$ gratings, respectively. While the fraction of elongated cells on each topography was small (less than $25 \%$ of total cell population), statistical significance was observed on $250 \mathrm{~nm}$ and $2 \mu \mathrm{m}$ PCL gratings compared to planar control $\left({ }^{*} p<0.05\right)$, and on $500 \mathrm{~nm}$ gratings $\left({ }^{* *} p<0.01\right)$. The average $R$-ratio of adherent cells on PCL gratings imprinted on glass was comparable to that of PCL gratings on Mylar, except for $250 \mathrm{~nm}$ gratings ( ${ }^{\#} p<0.01$ ) (Fig. 4C). The average $R$-ratios of cells on planar PCL $(0 \mathrm{~nm})$ imprinted on glass and on Mylar were significantly different $\left({ }^{\#} p<\right.$ 0.01 ), and marginally higher than that on planar TCPS and glass controls.

\subsection{RAW 246.7 response on constant height topography}

Compared to other cell types that have an increased $R$-ratio with decreased topographical size, the trend diverged in macrophage cells. We further investigated the topography-mediated changes in cell morphology by isolating the 3-dimensional effects with PDMS gratings varying in width but constant in pattern depth $(350 \mathrm{~nm})$. Cells were seeded on planar PDMS controls (Fig. 5A1-A3), $300 \mathrm{~nm}$ gratings (Fig. 5B1-B3), $500 \mathrm{~nm}$ gratings (Fig. 5C1-C3), and $1 \mu \mathrm{m}$ gratings (Fig. 5D1-D3). Topography-induced changes in cell adhesion, spreading and elongation were examined at $6 \mathrm{~h}$ (Fig. 5A1, B1, C1, D1), 24 h (Fig. 5A2, B2, C2, D2,) and 48 h (Fig. 5A3, B3, C3, D3). Adherent cells on PDMS gratings elongated along the parallel axis of gratings compared to planar controls.

Morphometric analysis of RAW 264.7 response to topography showed that cell adhesion density on $6 \mathrm{~h}$ samples was low (around $1 \times 100$ cells $/ \mathrm{mm}^{2}$ ) and did not increase above the cell seeding density (at $2 \times 100$ cells $/ \mathrm{mm}^{2}$ ) until between $24 \mathrm{~h}$ and $48 \mathrm{~h}$ (Fig. 5E), when proliferation occurred. However, cell adhesion density was comparable across all grating widths at each time point. Cell spreading of adherent macrophage was comparable across all grating sizes at $6 \mathrm{~h}$ and $24 \mathrm{~h}$, but increased significantly on $500 \mathrm{~nm}$ and $1 \mu \mathrm{m}$ gratings compared to planar PDMS control (Fig. 5F). Similar to macrophage adhesion and elongation on PCL gratings, the majority of adherent cells retained their native round shape (Fig. 5G) while elongated cells formed a small fraction, less than $15 \%$, of total cells (Fig. 5F). The low average $R$-ratio of all adherent cells ( $R<2$, Fig. 5I) was due to the round cells predominating in the sub-population ( $1.2<R<1.6$, Fig. 5I, inset). However, the elongated cells had a higher $R$-ratio $(R>3$, Fig. 5J). The effect of topography on fractional distribution of elongated cells and average $R$-ratio was not statistically significant. It was noted that cell elongation generally increased the average cell area compared to its native round shape on each topographical pattern (Supplementary Fig. 1).

\subsection{Cytokine secretion profile}

The cytokine secretion profile of RAW 264.7 cells cultured on PDMS samples was measured at $6 \mathrm{~h}, 24 \mathrm{~h}$ and $48 \mathrm{~h}$ using multiplex immunoassays. The cytokines examined were categorized into
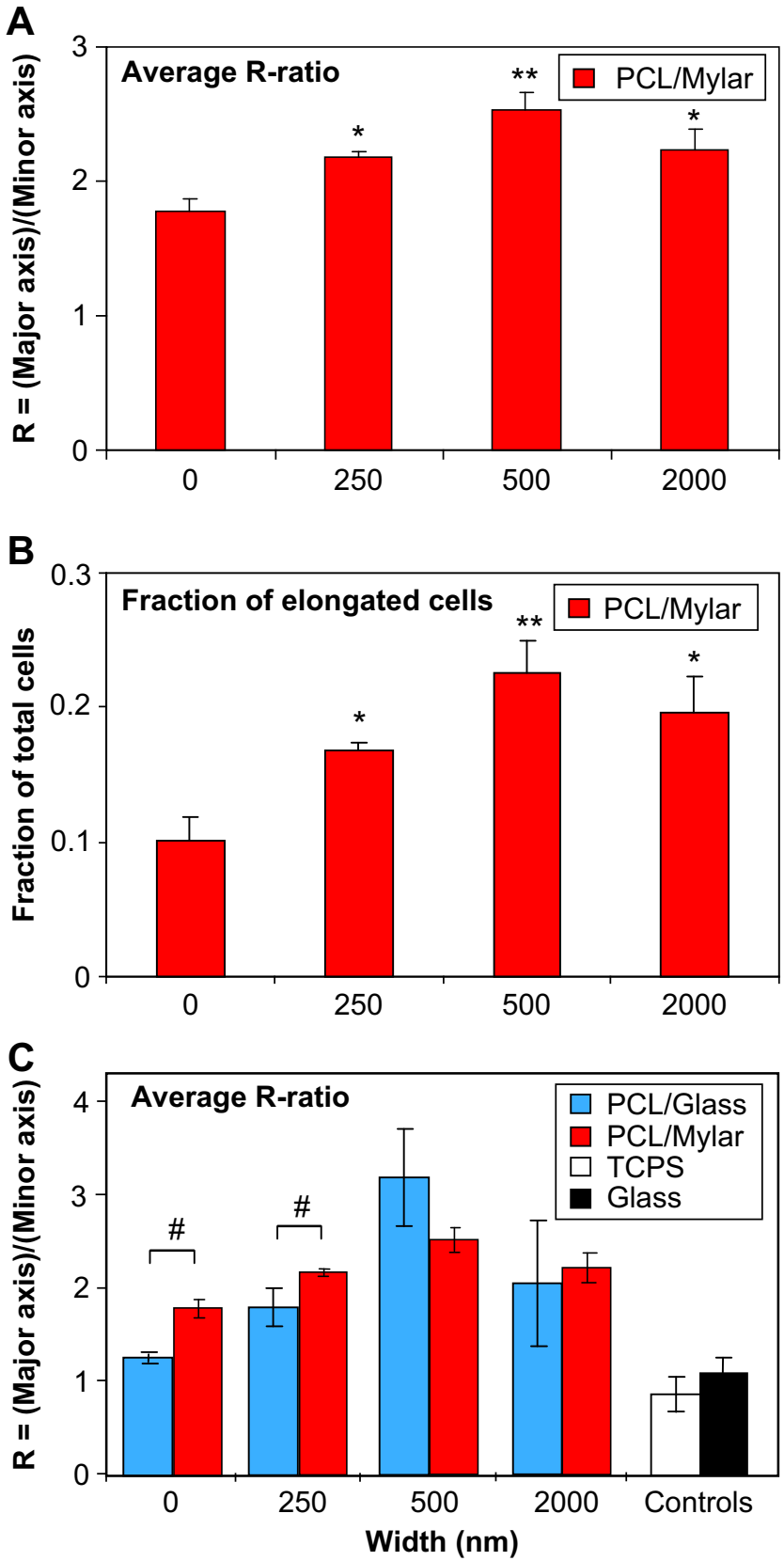

Fig. 4. Morphometric analysis of RAW 264.7 on NIL substrates. (A) The average elongation ratio, $R$-ratio = (length of major axis)/(length of minor axis), of adherent cells on PCL gratings imprinted on Mylar showed statistical significance on all grating sizes compared to planar PCL controls: $250 \mathrm{~nm}\left({ }^{*} p<0.05\right), 500 \mathrm{~nm}\left({ }^{*} p<0.01\right)$ and $2 \mu \mathrm{m}\left({ }^{*} p<0.05\right)$. The average $R$-ratio increased from planar to $500 \mathrm{~nm}$ gratings but decreased on $2 \mu \mathrm{m}$ gratings. (B) Of the total adherent cells, a small fraction $(<25 \%)$ of cells were elongated in the same direction (within $30^{\circ}$ angle) as the gratings. The changes in fraction of elongated cells (defined as $R \geq 2.5$ ) to topography shared the same trend as changes in average $R$-ratio, and were statistically significant compared to planar controls. (C) A comparison of average $R$-ratio on PCL gratings imprinted onto different treated surfaces (glass vs Mylar) showed similar trends of increasing up to $500 \mathrm{~nm}$ but decreasing at $2 \mu \mathrm{m}$, with statistical significance $(\# p<0.05)$ between cells on planar glass vs Mylar $(0 \mathrm{~nm})$ and between cells on $250 \mathrm{~nm}$ glass vs $250 \mathrm{~nm}$ Mylar Statistical analysis with student's $t$-test or one-way ANOVA comparison followed by Tukey's post-hoc test was used where needed. Statistical significance was noted at ${ }^{*} p<0.05$ and ${ }^{* *} p<0.01$.

pro-/anti-inflammation, and pro-/anti-wound healing according to their respective roles in the foreign body response $[9,10]$. TNF$\alpha$ (tumor necrosis factor- $\alpha$ ), MIP- $1 \alpha$ (macrophage inflammatory protein-1 $\alpha$ ), MCP-1 (monocyte chemoattractant protein-1) and 


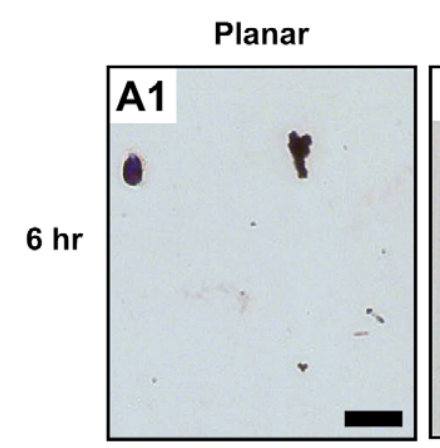

$300 \mathrm{~nm}$
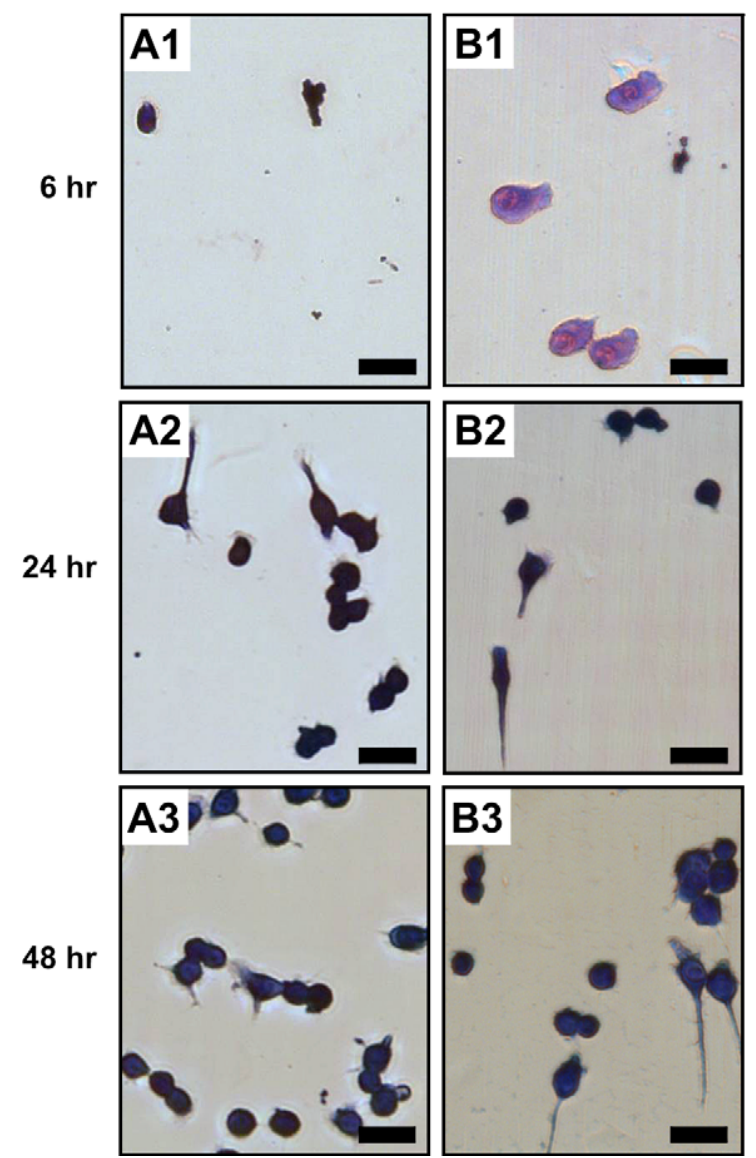
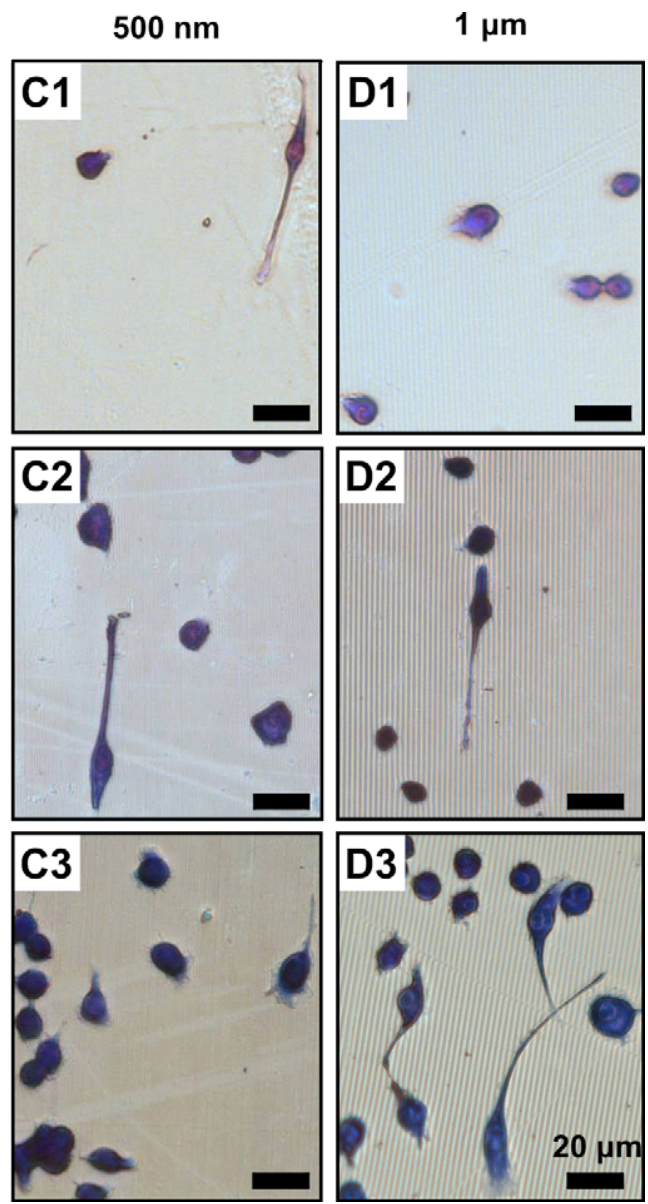

Fig. 5. RAW 264.7 response to PDMS topography. Photomicrographs of adherent cells on PDMS gratings and controls of constant height (at $350 \mathrm{~nm}$ ): planar control (Column A), 300 $\mathrm{nm}$ gratings (Column B), $500 \mathrm{~nm}$ gratings (Column D), and $1 \mu \mathrm{m}$ gratings. Across all gratings size, cell adhesion was observed on $6 \mathrm{~h}$ samples (A1-D1), while cell elongation in the direction of gratings was observed at $24 \mathrm{~h}$ (A2-D2), and $48 \mathrm{~h}$ (A3-D3). Morphometric analysis of adherent cells on PDMS topography showed (E) no statistical difference in cell adhesion density due to topography at $6 \mathrm{~h}, 24 \mathrm{~h}$ and $48 \mathrm{~h}$. (F) Cell spreading area was comparable at $6 \mathrm{~h}$ and $24 \mathrm{~h}$, but was considered significant on $500 \mathrm{~nm}(p<0.05)$ and $1 \mu \mathrm{m}$ gratings $(p<0.05)$ compared to planar control at $48 \mathrm{~h}(\mathrm{G})$ A major fraction of total adherent cells $(>85 \%)$ retain its native round shape, while $(\mathrm{H})$ a small fraction of cells $(<15 \%)$ acquired an elongated morphology of $R \geq 2.5$, with comparable levels across each pattern. (I) The average $R$-ratio of adherent cells $(R$-ratio $=1$ to 2 ) was similarly comparable to that of round cells (I, inset). In contrast, (J) the $R$-ratio of elongated cells on each topographical pattern was higher $(R$-ratio $=3$ to 4$)$ but was not considered statistically significant. Data is reported as mean \pm standard error of the mean (sample size, $n=3$ ). ANOVA/Tukey's post-hoc statistical test was used to examine data, and significance was determined at ${ }^{*} p<0.05$. Scale bar $=20 \mu \mathrm{m}$, May-Grünwald Giemsa stain, direction of gratings = vertical (B1-D3).

VEGF (vascular endothelial growth factor) cytokines were detected in the supernatant. To account for variation in cell density among the grating sizes, cytokine production was normalized to its respective cell number (Fig. 6). Supplementary Figs. 2 and 3 show the corresponding total cytokine production levels and relative expression of topography-induced cytokine secretion normalized to planar PDMS $(0 \mathrm{~nm})$, respectively. During the initial stages of cell adhesion and morphology change RAW 264.7 secreted proinflammatory/anti-wound healing cytokines TNF- $\alpha$, MIP- $1 \alpha$ and MCP-1. The temporal secretion of TNF- $\alpha$, MIP- $1 \alpha$ and MCP- 1 (pg/mL per 1000 cells) generally increased from $6 \mathrm{~h}$ to $24 \mathrm{~h}$, then decreased slightly at $48 \mathrm{~h}$ (Fig. 6A-C). In contrast, VEGF was low at $6 \mathrm{~h}-24 \mathrm{~h}$ $(<0.5 \mathrm{pg} / \mathrm{mL}$ per 1000 cells, Fig. $6 \mathrm{D})$, but increased at $48 \mathrm{~h}$. Between $24 \mathrm{~h}$ and $48 \mathrm{~h}$, the levels of pro-inflammatory cytokines TNF- $\alpha$, MIP- $1 \alpha$ and MCP- 1 were maintained or reduced, while VEGF, a proinflammation/pro-wound healing cytokine, increased. Together, these results suggest a transition from a pro-inflammatory cytokine profile (TNF- $\alpha$, MIP- $1 \alpha$, MCP- 1 ) at $6 \mathrm{~h}$ and $24 \mathrm{~h}$ towards a prowound healing cytokine profile (VEGF) at $48 \mathrm{~h}$.

A more detailed analysis of using ANOVA and Tukey's post-hoc test showed statistical significance in topography-induced TNF$\alpha$ secretion (Fig. 6A) at $6 \mathrm{~h}$, particularly on $1 \mu \mathrm{m}$ gratings compared to planar and $500 \mathrm{~nm}$ samples $\left({ }^{*} p<0.05\right)$. At $24 \mathrm{~h}$, increasing grating width increased TNF- $\alpha$ secretion $\left({ }^{*} p<0.001\right)$, but the trend was reversed at $48 \mathrm{~h}\left({ }^{*} p<0.05\right)$, with statistical significance noted for $1 \mu \mathrm{m}$ gratings compared to $300 \mathrm{~nm}$ gratings. The topographical effect on MIP-1 $\alpha$ secretion was difficult to discern (Fig. 6B) but significance was observed at $6 \mathrm{~h}$ for $300 \mathrm{~nm}$ samples compared to planar control $\left({ }^{*} p<0.05\right)$, at $24 \mathrm{~h}$ for $1 \mu \mathrm{m}$ gratings compared to $300 \mathrm{~nm}$ and $500 \mathrm{~nm}$ samples $\left({ }^{*} p<0.01\right)$, and at $48 \mathrm{~h}$ for $300 \mathrm{~nm}$, $500 \mathrm{~nm}$ and $1 \mu \mathrm{m}$ gratings compared to planar samples $\left({ }^{*} p<0.05\right)$. Similarly, the MCP-1 secretion profile shared the same trend as TNF- $\alpha$ secretion (Fig. 6C). Topography-induced MCP-1 secretion was most significant at $24 \mathrm{~h}\left({ }^{*} p<0.001\right)$ with increasing MCP-1 levels on increasing grating sizes: planar $\left({ }^{*} p<0.01\right), 300 \mathrm{~nm}\left({ }^{*} p<\right.$ $0.05)$ and $500 \mathrm{~nm}\left({ }^{*} p<0.05\right)$ compared to $1 \mu \mathrm{m}$ gratings, but was difficult to discern at $48 \mathrm{~h}$. VEGF cytokine secretion (Fig. 6D) responded significantly to topography at $6 \mathrm{~h}\left({ }^{*} p<0.05\right), 24 \mathrm{~h}\left({ }^{*} p<\right.$ $0.05)$, and $48 \mathrm{~h}\left({ }^{*} p<0.005\right)$. In particular at $48 \mathrm{~h}$, increasing grating width caused a significant decrease in VEGF levels, with the greatest decrease measured on $1 \mu \mathrm{m}$ gratings compared to other topographical samples: planar $\left({ }^{*} p<0.01\right), 300 \mathrm{~nm}$ gratings $\left({ }^{*} p<\right.$ $0.01)$ and $500 \mathrm{~nm}$ gratings $\left({ }^{*} p<0.05\right)$.

Patterns in topography-induced cytokine secretion were difficult to discern but greater statistical significance was observed for $24 \mathrm{~h}$ and $48 \mathrm{~h}$ readings. The pro-inflammatory and pro-wound 

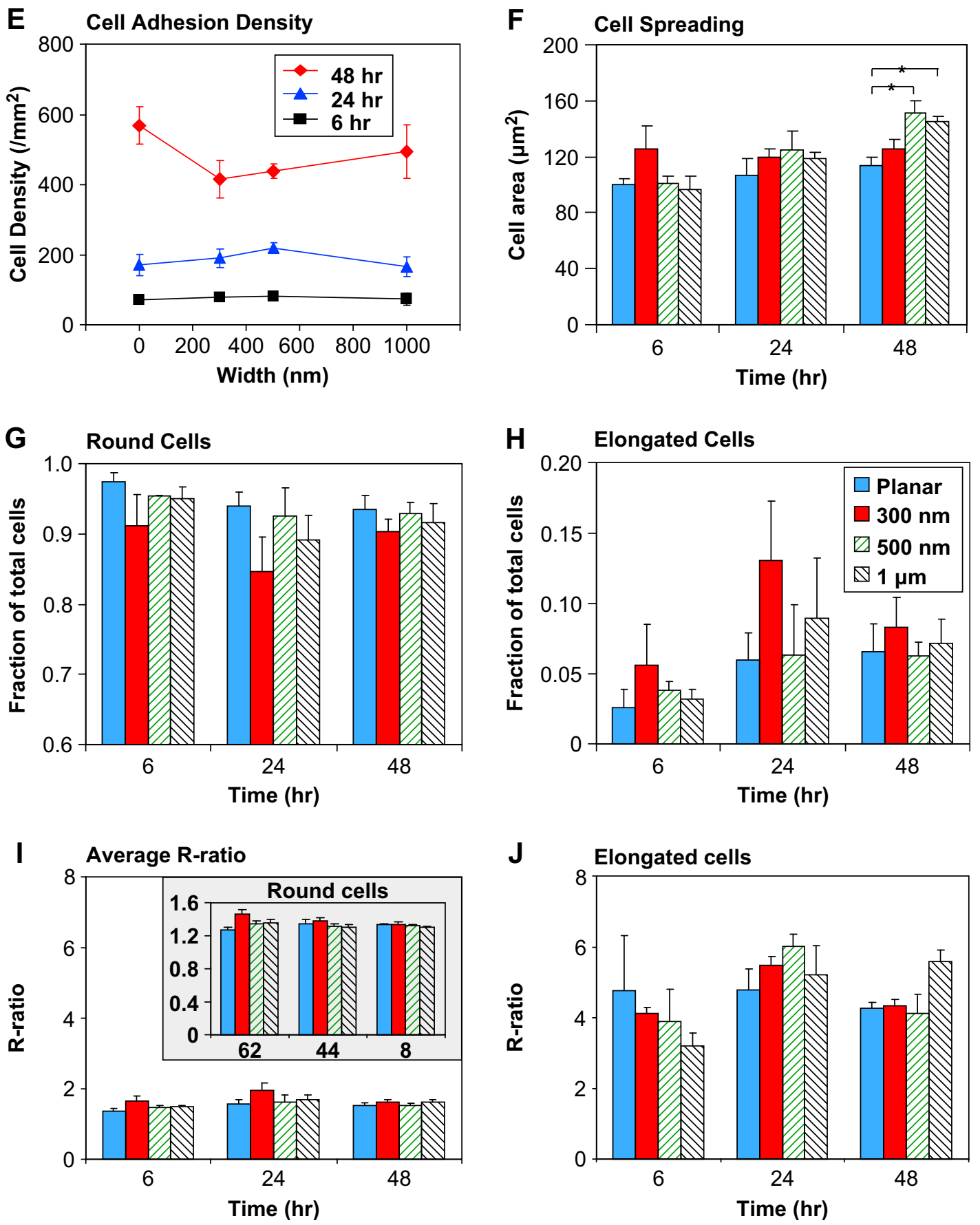

Fig. 5. (continued).

healing cytokine IL- $1 \beta$, and the anti-inflammatory and pro-wound healing cytokines IL-6, IL-10, and IL-12 were not detected in the supernatant (detection limit: $3.2 \mathrm{pg} / \mathrm{mL}$ ).

\subsection{In vivo characterization in the rat cage implant system}

The in vitro results of RAW 264.7 cells prompted us to investigate the corresponding in vivo macrophage response to topography. Samples of $2 \mu \mathrm{m}$ and $500 \mathrm{~nm}$ PCL gratings imprinted on Mylar (PCL/Mylar) were subcutaneously implanted into rats using the cage implant model, an established system for studying host tissue-implant response [44]. At Days 7 and 21, the implants were retrieved to examine macrophage attachment and FBGC fusion on the different gratings (Fig. 7A-F). As the subcutaneous cage implant system allows for cellular adhesion on both surfaces of the samples, the reverse side of the sample was used as a planar Mylar control $(0 \mathrm{~nm})$. Macrophage adhesion and foreign body giant cell (FBGC) fusion were present on all grating samples at Day 7 (Fig. 7A, C, E) and Day 21 (Fig. 7B, D, F). Cells became thinly spread and flattened on the PCL gratings. Cellular adhesion was determined based on the total number of nuclei in adherent cells, including macrophages and FBGCs. The density of adherent macrophage nuclei generally decreased from Days 7-21 (Fig. 7G) with comparable nuclei density observed on all grating samples, except for increased cell density on $2 \mu \mathrm{m}$ gratings compared to planar control at Day $21\left({ }^{*} p<0.05\right)$. 


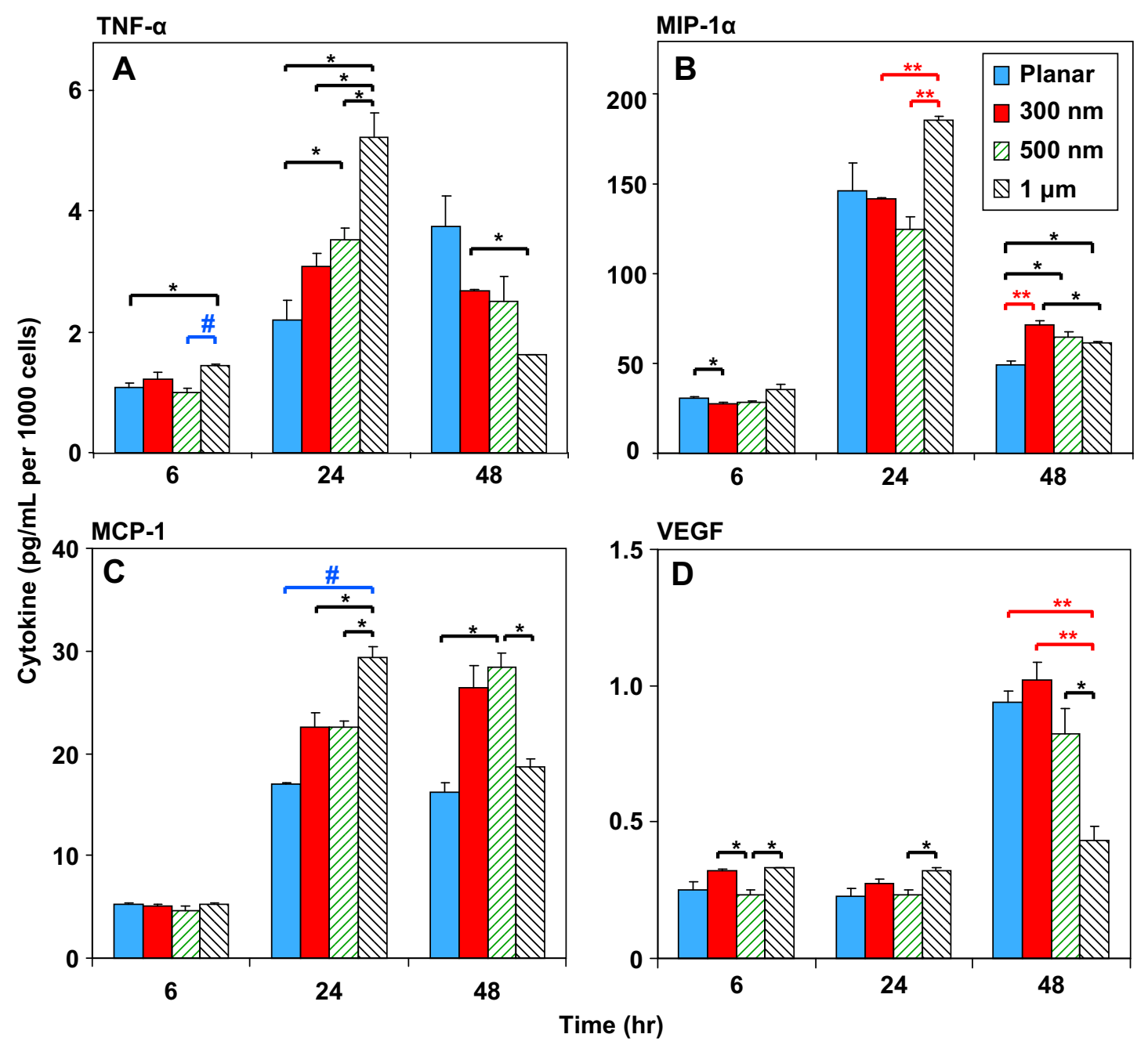

Fig. 6. Cytokine secretion profile normalized to cell number. The normalized cytokine secretion levels of cells (pg/mL per 1000 cells) in response to PDMS topography were detected using multiplex immunoassay for (A) TNF- $\alpha$, (B) MIP-1 $\alpha$, (C) MCP-1, and (D) VEGF. Data is reported as mean \pm standard error of the mean ( $n=3$ ). ANOVA/Tukey's post-hoc statistical test was used to examine data, and significance was determined at ${ }^{*} p<0.05, \# p<0.01,{ }^{* *} p<0.005$.

Due to the highly spread morphology of the stained adherent cells, it was difficult to distinguish FBGC borders from background staining. Instead of counting the fraction of nuclei contained within FBGCs, we estimated the percentage of fusion in each field-of-view categorically at $0 \%,<10 \%, 25 \% .50 \%, 75 \%,>90 \%$ or $100 \%$. A total of 24-72 fields-of-view were examined on 3-5 samples per grating size, and the percentage of fusion was presented as the percentage of fields-of-view with the corresponding categorical percentage fusion values. The extent of cell fusion was defined as low $(<10 \%)$, medium (25\%-75\%), or high fusion (>90\%), summarized in Table 2. At Day 7, fusion was minimal on all surfaces with $58-74 \%$ of fields having low $(<10 \%)$ or no fusion $(0 \%)$, and only $0-5 \%$ of fields with high fusion (>90\%). At Day 21, fusion increased on all surfaces. Approximately $25-55 \%$ of fields on surfaces registered high levels of fusion ( $>90 \%$ ) while only $28-37 \%$ of fields supported low fusion $(<10 \%)$. Topography-induced cellular fusion showed that low fusion decreased with increasing grating sizes at Day 7, but the trend reversed at Day 21 (Fig. $7 \mathrm{H}$ ). In contrast, high fusion was not prevalent at Day 7 but showed a decreasing trend with larger grating sizes.

No distinct patterns of cell elongation and alignment to the topographical substrates were observed at Days 7 or 21. While most adherent cells and FBGCs displayed a thinly spread morphology on the PCL/Mylar surfaces, some cells displayed elongated morphologies and the extension of pseudopodia in the direction of gratings, confirmed by SEM imaging (Supplementary Fig. 4). Cell elongation and pseudopodia presence indicated cellular migration across the surfaces.

\section{Discussion}

The nanoimprint lithography (NIL) fabrication technique allowed the introduction of PCL and PLA with topographical relief onto glass (optical clarity for microscopy) or Mylar (model implant biomaterial) substrates. Cellular studies were conducted on PCL and PLA topography with a residual layer to create a uniform surface chemistry between the ridges and troughs of the gratings. However, the contractile forces of adherent RAW 264.7 caused the polymer topography to delaminate over $24 \mathrm{~h}-48 \mathrm{~h}$. This necessitated the development of the stitching and embossing techniques to fabricate PDMS replicas that were inert, could withstand cell contractile forces, optically clear and with sufficiently large cell growth area for cellular studies.

Adhesion, elongation and alignment of RAW 264.7 to its underlying topography was clearly observed on PCL and PLA gratings (width:height:period $=1: 1: 2$ ) and on PDMS substrates of constant height (width:period $=1: 2$, height $=350 \mathrm{~nm}$ ), independent of surface chemistry. The lack of distinctive trends in cell 
Day 7
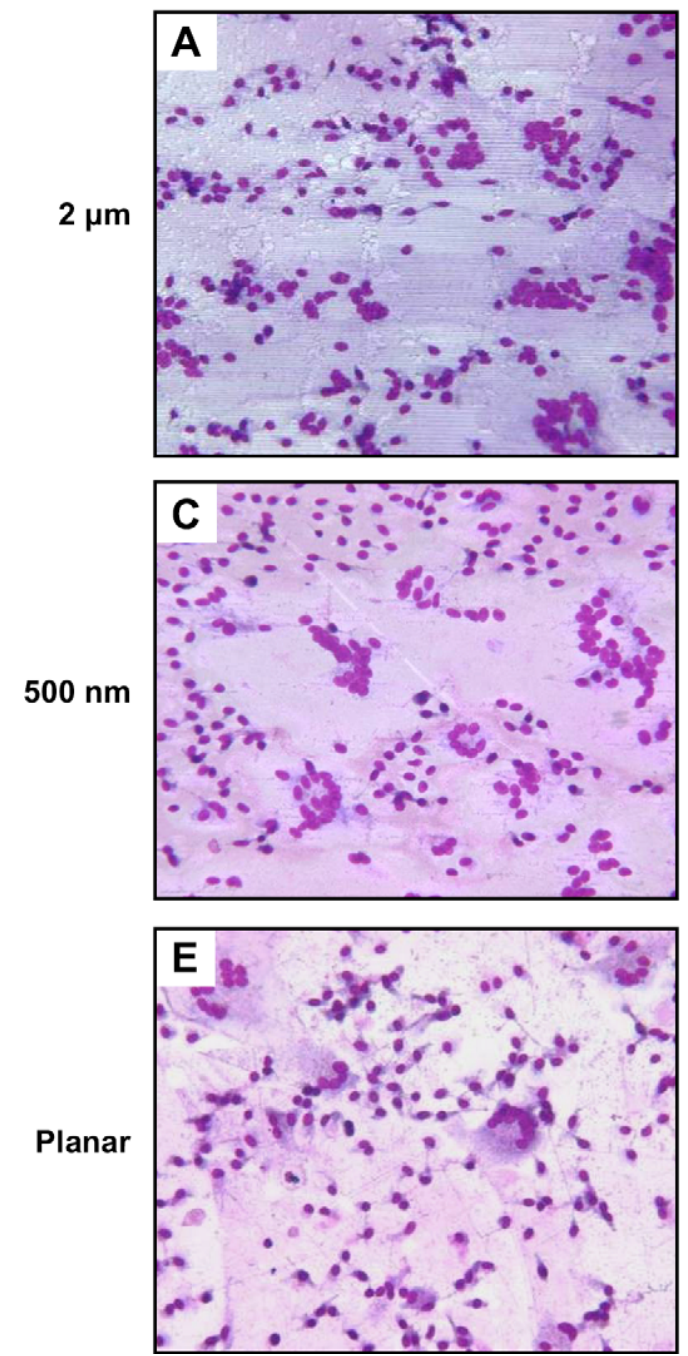

Day 21
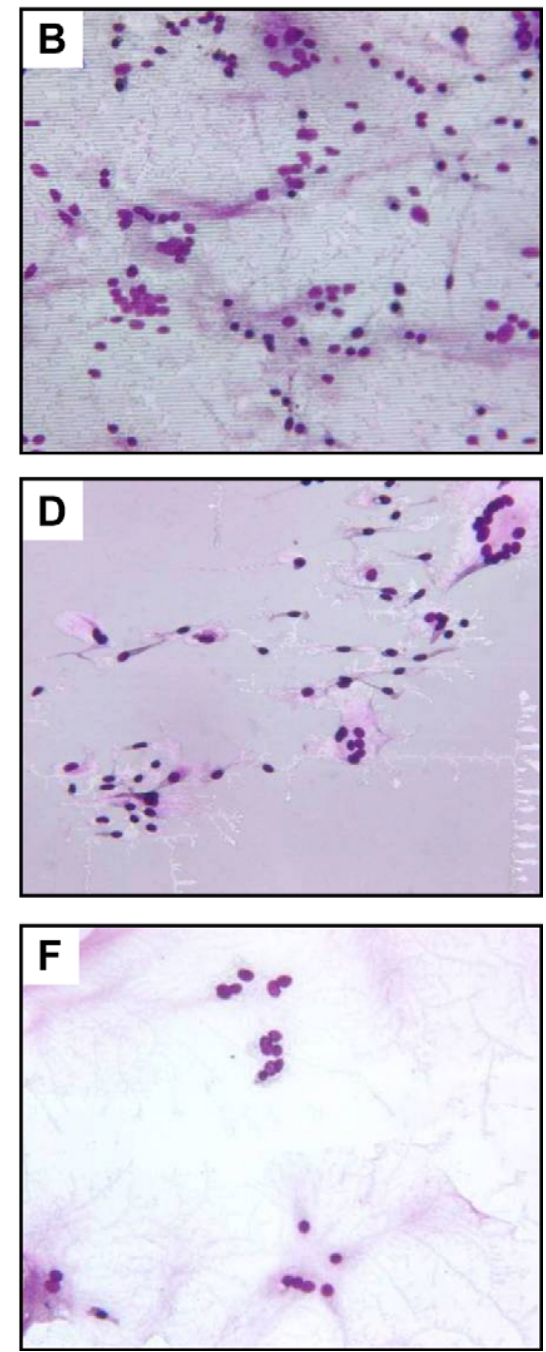

Fig. 7. In vivo cellular adhesion and fusion on PCL gratings imprinted on Mylar. Photomicrographs of macrophage cell adhesion and fusion on PCL/Mylar samples: (A-B) $2 \mu$ m gratings, (C-D) $500 \mathrm{~nm}$ gratings, and (E-F) planar Mylar control, at Day 7 (A, C, E) and Day 21 (B, D, F). (G) Cell adhesion density due to topography was comparable across all PCL gratings sizes at Day 7 (diamonds), then decreasing at Day 21 (squares). Adhesion density on $2 \mu \mathrm{m}$ PCL gratings was statistically significant compared to planar Mylar controls $\left({ }^{*} p<0.05\right)$. (H) Low fusion ( $<10 \%$ of fields with the corresponding percent FBGC fusion) decreased as grating size increased at Day 7 , but the trend was reversed on Day 21 . In contrast, high fusion ( $>90 \%$ of fields with the corresponding percent FBGC fusion) was low at Day 7 but increased at Day 21 , with a trend of decreasing high fusion on larger gratings. Magnification $=20 \times$, May-Grünwald Giemsa stain $(\mathrm{A}-\mathrm{F})$.

morphology and orientation changes of both RAW 264.7 and in vivo macrophage cells to the topography differed from our previous studies involving other cell types, such as mesenchymal stem cells [26] and smooth muscle cells [45], that showed over $80 \%$ cell elongation and alignment. Macrophage cells studies in our system showed that elongation increased with decreasing topography, but only to a limit of $500 \mathrm{~nm}$ before the trend diverged. Macrophage cells appeared to be relatively insensitive to nanotopography (less than $500 \mathrm{~nm}$ ), preferring to respond to $500 \mathrm{~nm}, 1 \mu \mathrm{m}$ and $2 \mu \mathrm{m}$ gratings. The phenomenon appears to mirror that of phagocytosis, where macrophages preferentially internalize particulates in the micron range over the nanometric range, with peak phagocytosis observed with particles of approximately $2 \mu \mathrm{m}$ in diameter [46-48]. The intrinsic properties of membrane ruffles in macrophages have been postulated to contribute to size sensitivity during the attachment step of phagocytosis of such particles [49]. Contractile forces exerted by macrophage cells during cell spreading, elongation and migration delaminated PCL nanogratings from its treated substrates and also distorted $1 \mu \mathrm{m}$ PDMS gratings in our studies
(Fig. 5). While the infinitely long parallel gratings, compared to a cell dimension, provide a non-phagocytosable surface, the limit of macrophage sensitivity to nanotopographical cues could be compared to a surface area dependence on pro-inflammation response, analogous to surface area dependence of nanoparticles in determining inflammatory response [50,51], and the influence of particle shape and size on internalization kinetics [52].

By measuring the functional response of macrophages in terms of its cytokine secretion profile, our results show that macrophages do respond to topographical cues in the early $6-48 \mathrm{~h}$ inflammation stage. TNF- $\alpha$ secretion has been implicated in inducing apoptosis of adherent macrophage on biomaterials [53], while MIP- $1 \alpha$ is involved in chemotaxis and recruitment of monocytes and leukocytes during the inflammatory response. The MIP- $1 \alpha$ secretion profile agreed with initial inflammation observed, followed by a transition towards pro-wound healing activity. MCP-1 (macrophage chemoattractant protein-1), a chemokine that recruits macrophage and promotes migration, also stimulates murine FBGC fusion in vivo [54]. VEGF promotes blood vessel dilation and 

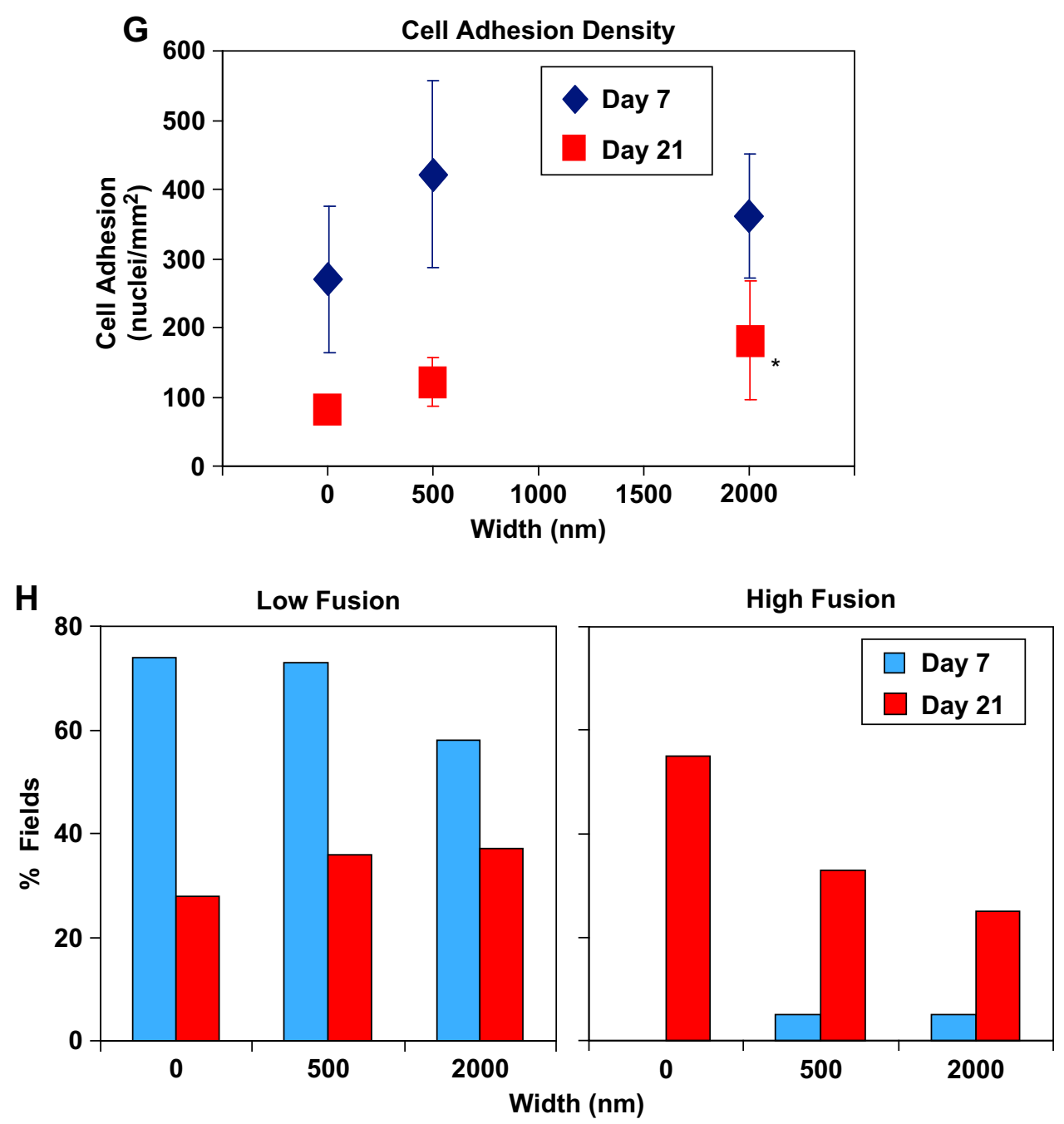

Fig. 7. (continued)

angiogenesis in the event of inflammation to promote wound healing in damaged tissue. Reduction of pro-inflammatory (TNF- $\alpha$ ) and pro-wound healing (VEGF) cytokine levels on $1 \mu \mathrm{m}$ gratings compared to planar and nanogratings suggest that inflammationrelated processes may be reduced on $1 \mu \mathrm{m}$ topography compared to nanogratings and planar controls.

We observed that topography affected in vivo macrophage functional response in terms of adherent cell density particularly on $2 \mu \mathrm{m}$ PCL gratings compared to planar controls. In the long term response (21 days), high cellular fusion ( $>90 \%$ ) was reduced as grating sizes increased: represented as high fusion on planar $>500$ $\mathrm{nm}>2 \mu \mathrm{m}$ (Fig. 7G). The larger topographical cues ( $2 \mu \mathrm{m}$ gratings) could be presenting a physical interruption or constraint to the fibrous scar tissue formation process, reducing cell adhesion density and limiting FBGC fusion on larger gratings compared to planar controls. Sanders et al. showed thinner in vivo fibrous

Table 2

In vivo $\mathrm{FBGC}$ fusion on $\mathrm{PCL} /$ Mylar gratings.

\begin{tabular}{|c|c|c|c|c|c|c|c|c|c|c|c|c|}
\hline \multirow[t]{3}{*}{ Day } & \multirow[t]{3}{*}{ Material } & \multirow{3}{*}{$\begin{array}{l}\text { Width } \\
(\mathrm{nm})\end{array}$} & \multicolumn{7}{|c|}{ Percentage of Fields with the Corresponding Percent Fusion ${ }^{a}$} & \multirow{3}{*}{$\begin{array}{l}\text { Low Fusion }^{\mathrm{b}} \\
<10 \%\end{array}$} & \multirow[t]{2}{*}{ Medium $^{c}$} & \multirow[t]{2}{*}{ High Fusion $^{\mathrm{d}}$} \\
\hline & & & \multicolumn{2}{|c|}{ Low Fusion } & \multicolumn{3}{|c|}{ Medium Fusion } & \multicolumn{2}{|c|}{ High Fusion $^{\mathrm{d}}$} & & & \\
\hline & & & $0 \%$ & $<10 \%$ & $25 \%$ & $50 \%$ & $75 \%$ & $>90 \%$ & $100 \%$ & & $25-75 \%$ & $>90 \%$ \\
\hline \multirow[t]{3}{*}{7} & Mylar & 0 & 56 & 18 & 12 & 12 & 3 & 0 & 0 & 74 & 27 & 0 \\
\hline & $500 \mathrm{~nm}$ & 500 & 55 & 18 & 15 & 5 & 3 & 5 & 0 & 73 & 23 & 5 \\
\hline & $2 \mu \mathrm{m}$ & 2000 & 43 & 15 & 20 & 5 & 13 & 5 & 0 & 58 & 38 & 5 \\
\hline \multirow[t]{3}{*}{21} & Mylar & 0 & 25 & 3 & 8 & 3 & 8 & 25 & 30 & 28 & 19 & 55 \\
\hline & $500 \mathrm{~nm}$ & 500 & 33 & 3 & 5 & 8 & 20 & 30 & 3 & 36 & 33 & 33 \\
\hline & $2 \mu \mathrm{m}$ & 2000 & 29 & 8 & 17 & 0 & 21 & 25 & 0 & 37 & 38 & 25 \\
\hline
\end{tabular}

\footnotetext{
a A total of 24-72 fields were analyzed on 3-5 samples.

b Summation of fields with $0 \%$ and $<10 \%$ fusion.

c Summation of fields with $25 \%, 50 \%$ and $75 \%$ fusion.

d Summation of fields with $>90 \%$ and $100 \%$ fusion.
} 
capsule formation around smaller microfibers (1-5 $\mu$ m diameter) compared to larger ones (6-10 $\mu \mathrm{m}$ diameter) for a variety of polymers [55], attributing these results to polymer surface curvature or cell-substrate contact area that minimally activates macrophages and its inflammatory response. Our results suggest that larger size topography $(500 \mathrm{~nm}-2 \mu \mathrm{m})$ limits macrophage activation and inflammation-related processes but topography-induced sensitivity reaches a limit around $500 \mathrm{~nm}$. Smaller topography (250-300 $\mathrm{nm}$ ) and planar controls may share the same adhesion and motility kinetics that result in the conventional macrophage adhesion, spreading and fusion observed during foreign body response. Although the intrinsic dynamic and plastic roles of the macrophage cell system may mask or cause an averaging of topography-induced response both in vitro and in vivo, the heterogeneity of cell morphologies observed (elongated and round cells) reflect the diverse plasticity of macrophage cells that define its myriad of phenotypes [56]. Macrophage desensitization to nanotopographical cues below $500 \mathrm{~nm}$ could be an advantage in motility and movement into different tissue types. Macrophages differentiate from non-adherent monocytic precursors that move throughout the vascular system into adherent macrophages that migrate into different organs and tissue, with specific functional roles that differ widely such as MHC (major histocompatibility complex) presentation in the innate immune response, phagocytosis, osteoclast fusion and bone resorption, and wound healing [57,58].

The consistent cellular response to three different types of polymers (PCL, PLA and PDMS) in our studies confirm that topography dictates changes in macrophage behavior, independent of surface chemistry. Topography-induced changes using our model surfaces could be examined at a greater number of time points and over a longer period of study to elucidate the complex cross-talk between cells and cytokines that varies temporally and spatially throughout the inflammation and wound healing process. Cellular changes observed in our studies focused on macrophages cultured on micro- and nanopatterns of fixed width parallel lines. The use of additional patterns and geometry in future studies, such as fixed width gratings of varying depths, pillars, pits or islands, would enhance our understanding of macrophage response to topography. Topography-induced change in macrophage behavior provides an opportunity to influence its phenotypic response such as cell activation, motility, maturation and fusion in the foreign body response without the addition of bioactive cues. Cellular responses to topography are known to affect cell function in terms of adhesion strength, spreading, intracellular signaling and differentiation potential [59-61]. This has been observed in various cell types including, but not limited to, mesenchymal stem cells [62-64], endothelial cells [65,66], fibroblasts $[67,68]$ and epithelial cells [69-71]. By improving our understanding of topographical effects on macrophage behavior, we may design biocompatible materials with optimal topographical cues that could mediate macrophage behavior in the foreign body reaction favorably.

\section{Conclusions}

This study suggests that topography may modulate the phenotypes of macrophages in the context of foreign body reaction. Although the response to topography in the form of gratings from micro- to submicron scale has not revealed a distinctive pattern, topography indeed affects cell morphology, cytokine secretion in vitro, and cell adhesion in vivo particularly for larger size patterns compared to planar controls. The changes in cell morphology are observed in three different types of polymers, indicating that the findings in this study are topography-mediated. The weak correlation between topographical features and macrophage response may be a reflection of the intrinsically dynamic, heterogeneous, and complex nature of the macrophage cell system, which might mask the relationship due to our limited time point investigation and ensemble analysis. The role of topography in modulating implanttissue reaction would require further elucidation; this study suggests that it is a fruitful direction that might impact biomaterials design.

\section{Conflict of interest statement}

The authors confirm that there are no known conflicts of interest associated with this publication and there has been no significant financial support for this work that could have influenced its outcome.

\section{Acknowledgements}

Support from NIH (grant numbers HL83008 and EB000282) is acknowledged. We are grateful to Dr. Yong Yang in teaching us the hybrid technique to fabricate a large nanopatterned surface area for cell culture. We also acknowledge the expertise of Wei Zhao in fabricating NIL-imprinted PCL on Mylar substrates.

\section{Appendix. Supplementary material}

Supplementary material associated with this paper can be found, in the online version, at doi:10.1016/j.biomaterials.2010.01. 074.

\section{Appendix}

Figures with essential colour discrimination. Most of the figures in this article have parts that are be difficult to interpret in black and white. The full colour images can be found in the online version, at doi:10.1016/j.biomaterials.2010.01.074.

\section{References}

[1] Williams DF, On the mechanisms of biocompatibility. Biomaterials 2008;29:2941-53.

[2] Anderson JM, Rodriguez A, Chang DT. Foreign body reaction to biomaterials Semin Immunol 2008;20:86-100.

[3] Ratner BD, Bryant SJ. Biomaterials: where we have been and where we are going. Annu Rev Biomed Eng 2004;6:41-75.

[4] Atienza C, Maloney WJ. Highly cross-linked polyethylene bearing surfaces in total hip arthroplasty. J Surg Orthop Adv 2008;17:27-33.

[5] Santerre JP, Woodhouse K, Laroche G, Labow RS. Understanding the biodegradation of polyurethanes: from classical implants to tissue engineering materials. Biomaterials 2005;26:7457-70.

[6] Ward B, Anderson J, McVenes R, Stokes K. In vivo biostability of polyether polyurethanes with fluoropolymer surface modifying endgroups: resistance to biologic oxidation and stress cracking. J Biomed Mater Res A 2007;80:33-44.

[7] Jones JA, Qin LA, Meyerson H, Kwon IK, Matsuda T, Anderson JM. Instability of self-assembled monolayers as a model material system for macrophage/FBGC cellular behavior. J Biomed Mater Res A 2008;84:158-66.

[8] Brodbeck WG, Nakayama Y, Matsuda T, Colton E, Ziats NP, Anderson JM Biomaterial surface chemistry dictates adherent monocyte/macrophage cytokine expression in vitro. Cytokine 2002;18:311-9.

[9] Brodbeck WG, Voskerician G, Ziats NP, Nakayama Y, Matsuda T, Anderson JM. In vivo leukocyte cytokine mRNA responses to biomaterials are dependent on surface chemistry. J Biomed Mater Res A 2003;64:320-9.

[10] Schutte RJ, Parisi-Amon A, Reichert WM. Cytokine profiling using monocytes macrophages cultured on common biomaterials with a range of surface chemistries. J Biomed Mater Res A 2009;88:128-39.

[11] Tang YW, Labow RS, Revenko I, Santerre JP. Influence of surface morphology and chemistry on the enzyme catalyzed biodegradation of polycarbonateurethanes. J Biomater Sci Polym Ed 2002:13:463-83.

[12] Refai AK, Textor M, Brunette DM, Waterfield JD. Effect of titanium surface topography on macrophage activation and secretion of proinflammatory cytokines and chemokines. J Biomed Mater Res A 2004;70:194-205.

[13] Ingram JH, Stone $M$, Fisher J, Ingham $E$. The influence of molecular weight, crosslinking and counterface roughness on TNF-alpha production by macrophages in response to ultra high molecular weight polyethylene particles. Biomaterials 2004;25:3511-22. 
[14] Irwin EF, Saha K, Rosenbluth M, Gamble LJ, Castner DG, Healy KE. Modulusdependent macrophage adhesion and behavior. J Biomater Sci Polym Ed 2008;19:1363-82.

[15] Fereol S, Fodil R, Labat B, Galiacy S, Laurent VM, Louis B, et al. Sensitivity of alveolar macrophages to substrate mechanical and adhesive properties. Cell Motil Cytoskeleton 2006;63:321-40.

[16] Voskerician G, Gingras PH, Anderson JM. Macroporous condensed poly(tetrafluoroethylene). I. In vivo inflammatory response and healing characteristics. J Biomed Mater Res A 2006;76:234-42.

[17] Williams D. The role of nitric oxide in biocompatibility. Med Device Technol 2008;19(8):10.

[18] Batchelor MM, Reoma SL, Fleser PS, Nuthakki VK, Callahan RE, Shanley CJ, et al. More lipophilic dialkyldiamine-based diazeniumdiolates: synthesis, characterization, and application in preparing thromboresistant nitric oxide release polymeric coatings. J Med Chem 2003;46:5153-61.

[19] Smith DJ, Chakravarthy D, Pulfer S, Simmons ML, Hrabie JA, Citro ML, et al. Nitric oxide-releasing polymers containing the $[\mathrm{N}(\mathrm{O}) \mathrm{NO}]-$ group. J Med Chem 1996;39:1148-56.

[20] Balasundaram G, Webster TJ. Nanotechnology and biomaterials for orthopedic medical applications. Nanomed 2006;1:169-76.

[21] McNally AK, DeFife KM, Anderson JM. Interleukin-4-induced macrophage fusion is prevented by inhibitors of mannose receptor activity. Am J Pathol 1996;149:975-85.

[22] DeFife KM, Jenney CR, McNally AK, Colton E, Anderson JM. Interleukin-13 induces human monocyte/macrophage fusion and macrophage mannose receptor expression. J Immunol 1997;158:3385-90.

[23] McNally AK, Anderson JM. Foreign body-type multinucleated giant cell formation is potently induced by alpha-tocopherol and prevented by the diacylglycerol kinase inhibitor R59022. Am J Pathol 2003;163:1147-56.

[24] McNally AK, Anderson JM. Beta1 and beta2 integrins mediate adhesion during macrophage fusion and multinucleated foreign body giant cell formation. Am J Pathol 2002;160:621-30.

[25] McNally AK, Jones JA, Macewan SR, Colton E, Anderson JM. Vitronectin is a critical protein adhesion substrate for IL-4-induced foreign body giant cell formation. J Biomed Mater Res A 2008;86:535-43.

[26] Yim EK, Pang SW, Leong KW. Synthetic nanostructures inducing differentiation of human mesenchymal stem cells into neuronal lineage. Exp Cell Res 2007;313:1820-9

[27] Dalby MJ, Gadegaard N, Curtis AS, Oreffo RO. Nanotopographical control of human osteoprogenitor differentiation. Curr Stem Cell Res Ther 2007;2: 129-38.

[28] Hansen JC, Lim JY, Xu LC, Siedlecki CA, Mauger DT, Donahue HJ. Effect of surface nanoscale topography on elastic modulus of individual osteoblastic cells as determined by atomic force microscopy. J Biomech 2007;40:2865-71.

[29] Dalby MJ, Gadegaard N, Wilkinson CD. The response of fibroblasts to hexagonal nanotopography fabricated by electron beam lithography. J Biomed Mater Res A 2008;84:973-9.

[30] Abrams GA, Bentley E, Nealey PF, Murphy CJ. Electron microscopy of the canine corneal basement membranes. Cells Tissues Organs 2002;170:251-7.

[31] Abrams GA, Murphy CJ, Wang ZY, Nealey PF, Bjorling DE. Ultrastructural basement membrane topography of the bladder epithelium. Urol Res 2003;31:341-6.

[32] Sanders JE, Stiles CE, Hayes CL. Tissue response to single-polymer fibers of varying diameters: evaluation of fibrous encapsulation and macrophage density. J Biomed Mater Res 2000;52:231-7.

[33] Cao H, McHugh K, Chew SY, Anderson JM. The topographical effect of electrospun nanofibrous scaffolds on the in vivo and in vitro foreign body reaction. J Biomed Mater Res A Epub date: 2009/09/22; doi:10.1002/jbm.a. 32609.

[34] Fink J, Fuhrmann R, Scharnweber T, Franke RP. Stimulation of monocytes and macrophages: possible influence of surface roughness. Clin Hemorheol Microcirc 2008;39:205-12.

[35] Spiller D, Mirtelli C, Losi P, Briganti E, Sbrana S, Counoupas C, et al. In vitro evaluation of the PEtU-PDMS material immunocompatibility: the influence of surface topography and PDMS content. J Mater Sci Mater Med 2009;20: 2511-20.

[36] Schulte VA, Diez M, Moller M, Lensen MC. Surface topography induces fibroblast adhesion on intrinsically nonadhesive poly(ethylene glycol) substrates. Biomacromolecules 2009;10:2795-801.

[37] Kong YP, Low HY, Pang SW, Yee AF. Duo-mold imprinting of three-dimensional polymeric structures. J Vac Sci Technol B 2004;22:3251-6.

[38] Xu Y, Zhao W, Low HY. Sacrificial film-assisted nanoimprint lithography. Microelectron Eng 2006;83:542-6.

[39] Huang XD, Bao LR, Cheng X, Guo LJ, Pang SW, Yee AF. Reversal imprinting by transferring polymer from mold to substrate. J Vac Sci Technol B 2002;20:2872-6.

[40] Guo LJ. Recent progress in nanoimprint technology and its applications. J Phys D Appl Phys 2004;37:R123-41.

[41] Marchant R, Hiltner A, Hamlin C, Rabinovitch A, Slobodkin R, Anderson JM. In vivo biocompatibility studies. I. The cage implant system and a biodegradable hydrogel. J Biomed Mater Res 1983;17:301-25.

[42] Kao WJ, Hubbell JA, Anderson JM. Protein-mediated macrophage adhesion and activation on biomaterials: a model for modulating cell behavior. J Mater Sci Mater Med 1999;10:601-5.
[43] Brodbeck WG, Patel J, Voskerician G, Christenson E, Shive MS, Nakayama Y, et al. Biomaterial adherent macrophage apoptosis is increased by hydrophilic and anionic substrates in vivo. Proc Natl Acad Sci U S A 2002;99:10287-92.

[44] Miller KM, Rose-Caprara V, Anderson JM. Generation of IL-1-like activity in response to biomedical polymer implants: a comparison of in vitro and in vivo models. J Biomed Mater Res 1989;23:1007-26.

[45] Yim EK, Reano RM, Pang SW, Yee AF, Chen CS, Leong KW. Nanopatterninduced changes in morphology and motility of smooth muscle cells. Biomaterials 2005;26:5405-13.

[46] Ahsan F, Rivas IP, Khan MA, Torres Suarez AI. Targeting to macrophages: role of physicochemical properties of particulate carriers-liposomes and microspheres - on the phagocytosis by macrophages. J Control Release 2002;79:29-40.

[47] Schafer V, von Briesen H, Andreesen R, Steffan AM, Royer C, Troster S, et al. Phagocytosis of nanoparticles by human immunodeficiency virus (HIV)-infected macrophages: a possibility for antiviral drug targeting. Pharm Res 1992;9:541-6.

[48] Tabata Y, Ikada Y. Effect of the size and surface charge of polymer microspheres on their phagocytosis by macrophage. Biomaterials 1988;9:356-62.

[49] Champion JA, Walker A, Mitragotri S. Role of particle size in phagocytosis of polymeric microspheres. Pharm Res 2008;25:1815-21.

[50] Limbach LK, Li Y, Grass RN, Brunner T], Hintermann MA, Muller M, et al. Oxide nanoparticle uptake in human lung fibroblasts: effects of particle size, agglomeration, and diffusion at low concentrations. Environ Sci Technol 2005;39:9370-6.

[51] Hussain S, Boland S, Baeza-Squiban A, Hamel R, Thomassen LC, Martens JA, et al. Oxidative stress and proinflammatory effects of carbon black and titanium dioxide nanoparticles: role of particle surface area and internalized amount. Toxicology 2009;260:142-9.

[52] Gratton SE, Ropp PA, Pohlhaus PD, Luft JC, Madden VJ, Napier ME, et al. The effect of particle design on cellular internalization pathways. Proc Natl Acad Sci U S A 2008;105:11613-8.

[53] Brodbeck WG, Shive MS, Colton E, Ziats NP, Anderson JM. Interleukin-4 inhibits tumor necrosis factor-alpha-induced and spontaneous apoptosis of biomaterial-adherent macrophages. J Lab Clin Med 2002;139:90-100.

[54] Kyriakides TR, Foster MJ, Keeney GE, Tsai A, Giachelli CM, Clark-Lewis I, et al. The CC chemokine ligand, CCL2/MCP1, participates in macrophage fusion and foreign body giant cell formation. Am J Pathol 2004;165:2157-66.

[55] Sanders JE, Bale SD, Neumann T. Tissue response to microfibers of different polymers: polyester, polyethylene, polylactic acid, and polyurethane. J Biomed Mater Res 2002:62:222-7.

[56] Mosser DM, Edwards JP. Exploring the full spectrum of macrophage activation. Nat Rev Immunol 2008;8:958-69.

[57] Vignery A. Macrophage fusion: molecular mechanisms. Methods Mol Biol 2008;475:149-61.

[58] Gimona M, Buccione R. Adhesions that mediate invasion. Int J Biochem Cell Biol 2006;38:1875-92.

[59] Kulangara K, Leong KW. Substrate topography shapes cell function. Soft Matter 2009;5:4072-6.

[60] Vogel V, Sheetz M. Local force and geometry sensing regulate cell functions. Nat Rev Mol Cell Biol 2006;7:265-75.

[61] Yim EK, Leong KW. Significance of synthetic nanostructures in dictating cellular response. Nanomedicine 2005;1:10-21.

[62] Yim EK, Darling EM, Kulangara K, Guilak F, Leong KW. Nanotopographyinduced changes in focal adhesions, cytoskeletal organization, and mechanical properties of human mesenchymal stem cells. Biomaterials Epub date: 2009/ 11/03; doi:10.1016/j.biomaterials.2009.10.037, S0142-9612(09)01143-0 [pii].

[63] Oh S, Brammer KS, Li YS, Teng D, Engler AJ, Chien S, et al. Stem cell fate dictated solely by altered nanotube dimension. Proc Natl Acad Sci U S A 2009;106:2130-5.

[64] Dalby MJ, Gadegaard N, Tare R, Andar A, Riehle MO, Herzyk P, et al. The control of human mesenchymal cell differentiation using nanoscale symmetry and disorder. Nat Mater 2007;6:997-1003.

[65] Hung HS, Wu CC, Chien S, Hsu SH. The behavior of endothelial cells on polyurethane nanocomposites and the associated signaling pathways. Biomaterials 2009;30:1502-11.

[66] Dalby MJ, Riehle MO, Johnstone H, Affrossman S, Curtis AS. In vitro reaction of endothelial cells to polymer demixed nanotopography. Biomaterials 2002;23:2945-54

[67] Dalby MJ, Riehle MO, Sutherland DS, Agheli H, Curtis AS. Use of nanotopography to study mechanotransduction in fibroblasts - methods and perspectives. Eur J Cell Biol 2004;83:159-69.

[68] Kim D-H, Han K, Gupta K, Kwon KW, Suh K-Y, Levchenko A. Mechanosensitivity of fibroblast cell shape and movement to anisotropic substratum topography gradients. Biomaterials 2009;30:5433-44.

[69] Andersson AS, Backhed F, von Euler A, Richter-Dahlfors A, Sutherland D, Kasemo B. Nanoscale features influence epithelial cell morphology and cytokine production. Biomaterials 2003;24:3427-36.

[70] Teixeira AI, McKie GA, Foley JD, Bertics PJ, Nealey PF, Murphy CJ. The effect of environmental factors on the response of human corneal epithelial cells to nanoscale substrate topography. Biomaterials 2006;27:3945-54.

[71] Karuri NW, Liliensiek S, Teixeira AI, Abrams G, Campbell S, Nealey PF, et al. Biological length scale topography enhances cell-substratum adhesion of human corneal epithelial cells. J Cell Sci 2004;117:3153-64. 